\title{
New Emission Inventory of Carbonaceous Aerosols from the On-road Transport Sector in India and its Implications for Direct Radiative Forcing over the Region
}

\author{
Jai Prakash ${ }^{1,2}$, Pawan Vats ${ }^{3}$, Amit Kumar Sharma ${ }^{3}$, Dilip Ganguly ${ }^{3}$, Gazala Habib ${ }^{*}$ \\ ${ }^{1}$ Department of Civil Engineering, Indian Institute of Technology Delhi, New Delhi 110016, India \\ ${ }^{2}$ Aerosol and Air Quality Research Laboratory, Washington University in St. Louis, MO 63130, USA \\ ${ }^{3}$ Centre for Atmospheric Sciences, Indian Institute of Technology Delhi, New Delhi 110016, India
}

\begin{abstract}
In this study, we categorized detailed mass-based emission factors (EFs) by age, calculated new estimates of fuel use, and developed spatially resolved emission inventories of constituents $\left(\mathrm{PM}_{2.5}\right.$, black carbon [BC], and organic carbon [OC]) in the fine aerosol generated by the on-road transport sector in India. On a national level, this sector released an estimated 355 (104-607) $\mathrm{Gg} \mathrm{y}^{-1}, 137$ (47-227) $\mathrm{Gg} \mathrm{y}^{-1}$, and 106 (34-178) $\mathrm{Gg} \mathrm{y}^{-1}$ of $\mathrm{PM}_{2.5}, \mathrm{BC}$, and OC, respectively, for the base year 2013 , contributing nearly $7 \%, 17 \%$, and $6 \%$ of the total emissions for each constituent. Although super-emitter vehicles comprised only $24 \%$ of the total traffic volume, they were responsible for $67 \%$ and $47 \%$ of the national $\mathrm{PM}_{2.5}$ and $\mathrm{BC}$ emissions, respectively, which indicates that eliminating these vehicles may rapidly reduce emissions from the on-road transport sector in India. To predict the direct radiative forcing (DRF) from BC emissions in this sector, we then input emission estimates for the carbonaceous aerosols into the Community Atmosphere Model (CAM5) global climate model and found a positive DRF of up to $6 \mathrm{~W} \mathrm{~m}^{-2}$ at the top of the atmosphere (TOA) and a negative DRF of up to $10 \mathrm{~W} \mathrm{~m}^{-2}$ at the surface, suggesting that as much as $16 \mathrm{~W} \mathrm{~m}^{-2}$ of energy remains trapped within the atmosphere. With the rapid economic growth and continued urbanization, the transport sector in India is likely to further expand in the future and hence requires immediate attention in order to reduce the $\mathrm{BC}$ burden and improve air quality in the nation.
\end{abstract}

Keywords: Emission factor; Black carbon; Organic carbon; Traffic volume; Climate forcing; BC burden.

\section{INTRODUCTION}

Development of a regionally representative EFs database is a prerequisite for preparing reliable emission estimates of anthropogenic aerosols and their precursors gases that are key input to climate models which are used as a tool for carrying out climate assessments (Reynolds et al., 2011; Bond et al., 2013; Pandey and Venkataraman, 2014). The net climate forcing by carbonaceous aerosols (BC and OC) can affect the temperature structure and winds in the atmosphere in a variety of ways at different scales (Wang, 2013). However, due to incorrect emission estimates of carbonaceous aerosols from South Asia, most climate models underestimate the aerosol burden over the region in their simulations and hence these models are generally associated with large uncertainty in terms of both magnitude and sign of climate forcing due to aerosols over South Asia (Bond et al., 2013). Among

\footnotetext{
${ }^{*}$ Corresponding author.

Tel.: 011-2659-1192

E-mail address: gazala@civil.iitd.ac.in
}

various combustion sources, the road transportation sector is already identified as one of the key emitters of carbonaceous aerosols in South Asia and especially in India (Pandey and Venkataraman, 2014). In fact, due to steadily increasing growth rate $(9.1 \%$ per year) noted in this sector, the carbonaceous aerosol emissions from the on-road transport sector in India are likely to surpass emissions from all other sectors in the near future (SIAM, 2017).

The existing global (Ohara et al., 2007; Borken et al., 2008; Zhang et al., 2009) and regional (Sahu et al., 2008; Guttikunda and Mohan, 2014; Sadavarte and Venkataraman, 2014; Paliwal et al., 2016) emission inventories of aerosols from South Asia often differ by almost a factor of 2-4. For road transport sector, most global emission inventories used the data reported by International Energy Outlook (U.S. EIA, 2013) for activity estimate, while the EFs (i.e., g of pollutant emitted (unit of fuel use) $)^{-1}$ ) is either from AP-42 database (U.S. EPA, 2011) or emission model (MOBILE 5.0) or literature based on dynamometer studies conducted in developed countries (Yanowitz et al., 2000; Zielinska et al., 2004). On the other hand, recently refined regional emission inventories (Pandey and Venkataraman, 2014) used the Tier III approach (IPCC, 2013) in the inventory development 
process for South Asia. These regional emission inventories incorporated state-level activity data and EFs from emission models and dynamometer studies conducted for Indian vehicles by the Automotive Research Association of India (ARAI) and the Central Pollution Control Board (CPCB) (ARAI, 2008, 2009). This approach has undoubtedly improved the regional emission estimates; however, the use of EFs from dynamometer experiments and emission models are not representative of real-world emissions as shown by several researchers (Grieshop et al., 2012; Goel and Guttikunda, 2015; Choudhary and Gokhale, 2016). These limited onroad emission measurement exercises in India have indicated that several factors including driving behavior, traffic congestion, road conditions, fuel tarnishing, engine capacity, load, and after-treatment techniques can strongly affect the emission profile from the on-road transportation sector in India. These variables are hard to simulate in a laboratory using a particular standard driving cycle. Hence, dynamometer studies are reasonable effort to study the engine performance against the compliance, but it fails to simulate real-world driving condition and therefore, emissions.

Therefore, this work presents new emission estimates of $\mathrm{PM}_{2.5}$, EC (or BC), and OC from the on-road transport sector in India by overcoming some of the drawbacks of the earlier regional emission inventories. In the present work, EFs calculated from aerosol mass collected during on-road operation of light-duty passenger cars in Delhi. The new EFs, coupled with revised fuel consumption based on Tier III approach improved the emission estimates from the 4-wheeler passenger cars and considerably reduce the overall uncertainty associated with emission estimates. Emissions from other vehicle categories (HDV, LMV-commercial, tractor, and trailer) also estimated by multiplying the EFs reported in the literature with the fuel use determined in the present work. To examine the contribution of low- and high-emitting technology, we also quantified the on-road population of super-emitters and non-super-emitters vehicle and estimated their fuel consumptions and emissions. Further spatial distribution of emission fluxes $\left(0.25^{\circ} \times 0.25^{\circ}\right.$ resolution $)$ of $\mathrm{BC}$ for the year 2013 was used to estimate the $\mathrm{BC}$ atmospheric burden and direct radiative forcing (DRF) over the region using CAM5 global climate model.

\section{MATERIAL AND METHODS}

\section{Total Emission Estimate}

The present national emissions of $\mathrm{PM}_{2.5}$, EC (onwards referred to as $B C$ due to climate relevance), and $\mathrm{OC}$ are estimated for on-road transport sector of India for the base year 2013, which comprises new political states renowned after 2011. A schematic flow chart of emission estimation methodology has been presented in the supplementary information (SI; Fig. S1).

In brief, the national-level emissions of a given pollutant "p" from vehicle type "i" of various age group A-C and super-emitter (SE) using fuel type " $\mathrm{k}$ " was estimated by multiplying the consumption of mass of fuel of type " $k$ " (in $\mathrm{kg}$ ) with mass-based emission factor (in $\mathrm{g} \mathrm{kg}^{-1}$ ) of pollutant "p" for a given vehicle and fuel type (Eq. (1)). The age group defined as A (2010-2013), B (2006-2009), C (2001-2005) and SE (super-emitter age group before the year 2000 and older and $17 \%$ from each category (A-C) (Fig. S1).

$$
E_{p, i, k, A-C, S E}=\sum_{s=1}^{36} F_{s, i, k, A-C, S E} \times E F_{p, i, k, A-C, S E}
$$

\section{Emission Factors}

In previous emission estimates, on-road vehicle EFs were used either from laboratory, modeled, or derived EFs (ARAI, 2008; Pandey and Venkatraman, 2014). Our motivation in the present work, the new distance-based EFs $\left(\mathrm{g} \mathrm{km}^{-1}\right)$ of $\mathrm{PM}_{2.5}$, OC, and BC for diesel-, gasoline-, and CNG-powered 4-wheeler (4W), 2-wheeler (2W; 4S), and LMV-passenger (3-wheeler, or $3 \mathrm{~W}$ ) vehicles of different age groups $\mathrm{A}$ (2010-2013), B (2006-2009), C (2001-2005) were adopted from our companion paper Jaiprakash and Habib (2017) and converted to mass-based EFs $\left(\mathrm{g} \mathrm{kg}^{-1}\right)$ by multiplying it with fuel economy (listed in Table S1) and fuel density reported for Indian fuel (SIAM, 2010). In our companion paper, the tailpipe emissions are measured in 3 repetitive on-road experiments for diesel-, gasoline-, and CNG-powered 4wheelers, which driven outside the IIT Delhi campus on a $10 \mathrm{~km}$ sampling route comprised of heterogeneous traffic $(2 \mathrm{~W}, 3 \mathrm{~W}, 4 \mathrm{~W}$, and bicycles etc.) and 6 traffic signals. One should note that the EFs measured on $10 \mathrm{~km}$ stretch may not be representative of the entire country, however, due to the challenges in on-road measurement involving the continuous power supply to generate clean dilution air for diluting exhaust limited the measurement duration to $45-60 \mathrm{~min}$. We still believe that the EFs are representative for congested urban roads of cities of India. The further improvement in emission factor database can be acquired by conducting the emission measurement in other cities of India using an identical systematic approach. The emissions from $2 \mathrm{~W}$ (4S) and LMV-passenger $(3 \mathrm{~W}) \mathrm{CNG}$ are measured at the stationary position by operating the vehicles with suspended wheels according to Modified Indian Driving Cycle (MIDC) method (ARAI, 2008).

The EFs of LMV-goods, HDV-trucks, buses (diesel and $\mathrm{CNG}$ ) and others (such as tractor and trailer) as reported in published literature ARAI $(2008,2009)$ used in the present work. Since the EFs of Age Group A is not available in the literature (ARAI, 2008, 2009), hence the same EFs for Age Group B vehicles were applied in Age Group A for the emission calculation. In the absence of appropriate information, the average $\mathrm{OC} / \mathrm{PM}_{2.5}$ and $\mathrm{BC} / \mathrm{PM}_{2.5}$ ratios reported in ARAI (2009) and Jaiprakash and Habib (2017) for Indian vehicles are used to calculate OC and BC EFs in the present study. The ratios reported for vehicles from other countries (Alves et al., 2011; May et al., 2014) might be significantly different from values used in present work; however, we limited our assessment with emission factor database available for Indian vehicles to avoid the introduction of an unknown source of uncertainty. The $\mathrm{PM}_{2.5}$ EFs of "other vehicles" (tractors/trailers) are taken from Ramachandra et al. (2015), and the same ratio is used to calculate OC and BC EFs. The EFs for all categories of non- 
super-emitter vehicles averaged for the age groups of A, B, $\mathrm{C}$ and listed in Table 1.

Generally, we assumed that old vehicle could be "superemitter" vehicle, while few researchers explained that superemitter is the fraction of vehicles which are poorly maintained or defective, and that could be from "old" or "new" vehicles on the fleet. Therefore, due to absence of their age, we averaged the EFs of vehicles older than the year 2000 or before from previous studies (Bond et al., 2004; ARAI, 2008, 2009; Subramanian et al., 2009; Sadavarte and Venkataraman, 2014; Goel and Guttikunda, 2015). Additionally, the EFs reported from any vehicle emitting two times or higher than the non-super-emitters also considered as super-emitters.

\section{Fuel Use Estimate}

Previous fuel estimation for the on-road transport sector, both approach "top" and "bottom" were used based on national or survey reports (Baidya and Borken-Kleefeld, 2009; Sahu et al., 2014). In the present work, the fuel use estimate followed the Tier III approach for the on-road transport sector. In order to estimate fuel use in the present work, detailed on-road vehicle population using a survival model, annual distance travel, and fuel economy discussed in Section A1 in SI. The annual distance travel and fuel economy for different vehicle categories compiled in Tables S1 and S2. The uncertainty on fuel use and propagates to total emission also discussed in Section A2.

\section{Estimation of Super-emitters Vehicle}

A small fraction of vehicles with poor maintenance or with outdated technology that contributes significantly towards the total emissions are termed as "super-emitters" (Bond et al., 2004; Subramanian et al., 2009; Yan et al., 2014). The super-emitter fraction for Indian cities is not available. Nevertheless, Bond et al. (2004) assumed superemitter fraction of vehicles to be in the range 5-60\% for Asian countries and a recent study (Huo et al., 2012) reported the super-emitter fraction in China as $23 \%$. Therefore, the present study applied the geometric mean $(17 \%)$ of the super-emitter fraction range reported by Bond et al. (2004) on vehicles population of Age Groups A, B, C and added all the vehicles of the model year 2000 and earlier. Finally, the super-emitter on-road population fraction estimated as $25 \%$ of the total, which is close to the value reported for China (Huo et al., 2012).

\section{Gridded Emission Inventory}

The total emission of $\mathrm{PM}_{2.5}, \mathrm{BC}$, and $\mathrm{OC}$ from the on-road transportation sector in India for the base year 2013 spatially distributed into grids across the country. For preparing this gridded emission inventory, appropriate proxies are considered according to district-level (641 districts in India) activities of

Table 1. Fuel-based average emission factors $\left(\mathrm{g} \mathrm{kg}^{-1}\right)$ of $\mathrm{PM}_{2.5}, \mathrm{BC}$, and $\mathrm{OC}$ for non-super-emitter vehicles.

\begin{tabular}{|c|c|c|c|c|c|c|c|c|c|}
\hline & $\mathrm{A}$ & $\mathrm{B}$ & $\mathrm{C}$ & $\mathrm{A}$ & $\mathrm{B}$ & $\mathrm{C}$ & $\mathrm{A}$ & $\mathrm{B}$ & $\mathrm{C}$ \\
\hline & \multicolumn{3}{|c|}{$\mathrm{PM}_{2.5}$} & \multicolumn{3}{|c|}{$\mathrm{BC}$} & \multicolumn{3}{|c|}{$\mathrm{OC}$} \\
\hline \multicolumn{10}{|l|}{ Diesel } \\
\hline $\begin{array}{l}\text { LMV-Goods } \\
(3 \mathrm{~W})\end{array}$ & $2.9 \pm 1.7$ & $2.9 \pm 1.7$ & $9.9 \pm 6.0$ & $1.9 \pm 0.8$ & $1.9 \pm 0.8$ & $6.6 \pm 2.6$ & $0.9 \pm 0.3$ & $0.9 \pm 0.3$ & $3.0 \pm 1.2$ \\
\hline $\begin{array}{l}\text { LMV-Goods } \\
(4 \mathrm{~W})\end{array}$ & $5.3 \pm 1.1^{\mathrm{a}}$ & $6.5 \pm 1.5^{\mathrm{a}}$ & $11.2 \pm 7.0$ & $3.4 \pm 1.0^{\mathrm{a}}$ & $3.0 \pm 1.0^{\mathrm{a}}$ & $7.8 \pm 4.8$ & $0.5 \pm 0.1^{\mathrm{a}}$ & $1.1 \pm 0.1^{\mathrm{a}}$ & $3.3 \pm 2.0$ \\
\hline Passenger car & $5.3 \pm 1.1^{\mathrm{a}}$ & $6.5 \pm 1.5^{\mathrm{a}}$ & $1.8 \pm 0.5^{\mathrm{a}}$ & $3.4 \pm 1.0^{\mathrm{a}}$ & $3.0 \pm 1.0^{\mathrm{a}}$ & $0.8 \pm 0.2^{\mathrm{a}}$ & $0.5 \pm 0.1^{\mathrm{a}}$ & $1.1 \pm 0.1^{\mathrm{a}}$ & $0.4 \pm 0.4^{\mathrm{a}}$ \\
\hline HDV & $1.7 \pm 0.4$ & $1.7 \pm 0.4$ & $7.8 \pm 0.8$ & $1.1 \pm 0.2$ & $1.1 \pm 0.2$ & $5.5 \pm 0.5$ & $0.4 \pm 0.1$ & $0.4 \pm 0.1$ & $1.6 \pm 0.2$ \\
\hline Bus & $1.7 \pm 0.4$ & $1.7 \pm 0.4$ & $5.5 \pm 1.2$ & $1.1 \pm 0.2$ & $1.1 \pm 0.2$ & $3.9 \pm 0.8$ & $0.4 \pm 0.1$ & $0.4 \pm 0.1$ & $1.1 \pm 0.2$ \\
\hline Other $\$$ & $1.1 \pm 0.2$ & $1.1 \pm 0.2$ & $1.1 \pm 0.2$ & $0.7 \pm 0.2$ & $0.7 \pm 0.2$ & $0.8 \pm 0.2$ & $0.3 \pm 0.1$ & $0.3 \pm 0.1$ & $0.2 \pm 0.1$ \\
\hline \multicolumn{10}{|l|}{ Gasoline } \\
\hline 2-wheeler (2S) & $2.2 \pm 0.4$ & $2.2 \pm 0.4$ & $3.0 \pm 0.1$ & $0.11 \pm 0.04$ & $0.11 \pm 0.04$ & $0.14 \pm 0.06$ & $1.3 \pm 0.5$ & $1.3 \pm 0.5$ & $1.7 \pm 0.7$ \\
\hline 2-wheeler (4S) & $0.5 \pm 0.4^{\mathrm{a}}$ & $0.5 \pm 0.2^{\mathrm{a}}$ & $1.5 \pm 0.4^{\mathrm{a}}$ & $0.03 \pm 0.0^{\mathrm{a}}$ & $0.04 \pm 0.01^{\mathrm{a}}$ & $0.17 \pm 0.04^{\mathrm{a}}$ & $0.3 \pm 0.1^{\mathrm{a}}$ & $0.3 \pm 0.1^{\mathrm{a}}$ & $0.9 \pm 0.2^{\mathrm{a}}$ \\
\hline $\begin{array}{l}\text { LMV-passenger } \\
(3 \mathrm{~W})\end{array}$ & $1.3 \pm 0.3$ & $1.3 \pm 0.3$ & $1.3 \pm 0.3$ & $0.07 \pm 0.03$ & $0.07 \pm 0.03$ & $0.06 \pm 0.03$ & $0.8 \pm 0.4$ & $0.8 \pm 0.4$ & $0.7 \pm 0.4$ \\
\hline $\begin{array}{l}\text { Passenger car } \\
\text { CNG }\end{array}$ & $0.7 \pm 0.3^{\mathrm{a}}$ & $1.4 \pm 0.4^{\mathrm{a}}$ & $1.4 \pm 0.4^{\mathrm{a}}$ & $0.05 \pm 0.01^{\mathrm{a}}$ & $0.08 \pm 0.02^{\mathrm{a}}$ & $0.20 \pm 0.04^{\mathrm{a}}$ & $0.7 \pm 0.4^{\mathrm{a}}$ & $0.8 \pm 0.4^{\mathrm{a}}$ & $0.7 \pm 0.7^{\mathrm{a}}$ \\
\hline $\begin{array}{l}\text { LMV-passenger } \\
(3 \mathrm{~W})\end{array}$ & $0.4 \pm 0.1^{\mathrm{a}}$ & $0.8 \pm 0.3^{\mathrm{a}}$ & $3.3 \pm 1.1^{\mathrm{a}}$ & $0.01 \pm 0.01^{\mathrm{a}}$ & $0.09 \pm 0.05^{\mathrm{a}}$ & $0.20 \pm 0.05^{\mathrm{a}}$ & $0.3 \pm 0.1^{\mathrm{a}}$ & $0.4 \pm 0.1^{\mathrm{a}}$ & $1.8 \pm 0.6^{\mathrm{a}}$ \\
\hline Car (4W) & $4 \pm 0.1^{\mathrm{a}}$ & $0.4 \pm 0.1^{\mathrm{a}}$ & $1.1 \pm 0.4^{\mathrm{a}}$ & $0.01 \pm 0.002^{\mathrm{a}}$ & $0.02 \pm 0.00^{\mathrm{a}}$ & $0.20 \pm 0.13^{\mathrm{a}}$ & $0.3 \pm 0.1^{\mathrm{a}}$ & $0.2 \pm 0.1^{\mathrm{a}}$ & $0.2 \pm 0.1^{\mathrm{a}}$ \\
\hline Bus & $2.0 \pm 1.1$ & $2.1 \pm 0.4$ & $2.1 \pm 0.7$ & $0.10 \pm 0.04$ & $0.10 \pm 0.01$ & $0.10 \pm 0.03$ & $1.1 \pm 0.4$ & $1.0 \pm 0.1$ & $1.1 \pm 0.4$ \\
\hline
\end{tabular}

Vehicle age groups classified as: $\mathrm{A}=2010-2013 ; \mathrm{B}=2006-2009 ; \mathrm{C}=2001-2005$.

LMV: Light motor vehicle: diesel-fueled 3-wheeler (3W) and 4-wheeler (4W) used as commercial vehicles.

${ }^{a}$ Emission factors are taken from our companion paper (Jaiprakash and Habib, 2017) and converted to fuel-based emission factors of $\mathrm{PM}_{2.5}, \mathrm{BC}$, and $\mathrm{OC}$.

The emission factors of LMV-goods, HDV-trucks, buses, LMV-passenger (3W-gasoline), 2-wheelers (2S), CNG buses were adopted from ARAI $(2008,2009)$ for $\mathrm{PM}_{2.5}$, while average fraction of $\mathrm{BC} / \mathrm{PM}_{2.5}$ and $\mathrm{OC} / \mathrm{PM}_{2.5}$ were adopted from ARAI (2008, 2009) and Jaiprakash and Habib (2017) for deriving emission factors of BC and OC.

${ }^{\$} \mathrm{PM}_{2.5}$ emission factors of other vehicles (tractor and trailers) were adopted from Ramachandra et al. (2015). 
the road transport sector in India and illustrated in Table S3. The whole India divided into 16,384 grid cell and each cell has $0.25^{\circ} \times 0.25^{\circ}$ resolution. Total emissions from dieselfueled vehicles and their super-emitters are distributed gridwise following Pandey et al. (2014) and by assuming fixed fractions of road densities of "golden quadrilateral" roads $(30 \%)$, national highways $(40 \%)$, state highways $(20 \%)$, and urban grids (10\%) across the country. In the absence of exact information on road density for each grid, we followed the assumptions made by Pandey et al. (2014) for consistency with other recently published emission estimates. The uncertainties associated with assumed road density distribution are $\pm 7.5 \%, \pm 10 \%, \pm 5 \%$, and $\pm 2.5 \%$ for "golden quadrilateral" road, national highways, state highways, and urban grids, respectively (personal communication from Dr. Sarath Guthikunda). Furthermore, the proxy of gasoline vehicles was taken as urban population of districts grids following Pandey et al. (2014). Spatial distribution of $\mathrm{PM}_{2.5}, \mathrm{BC}$, and OC has been visualized using ArcGIS software (10.1).

\section{Climate Model Description and Simulation Details}

We use a variant of the three-dimensional global climate model called the Community Earth System Model (CESM1, released version 1.2) developed at the National Center of Atmospheric Research (NCAR) (Hurrell et al., 2013). The direct radiative forcing over the Indian region due to emissions of $\mathrm{BC}$ from the on-road transportation sector in India estimated. The uncertainty in $\mathrm{BC}$ emission estimates is $33 \%$; therefore, the radiative forcing calculation is expected to be well bounded. The earlier study also used BC emission from transport sector with 33\% uncertainty for radiative forcing (Fuglestvedt et al., 2008).

The atmospheric components of CESM1 version used here are the Community Atmosphere Model (CAM5.3). The CAM5.3 has a hydrostatic, finite-volume (FV) dynamical core with a horizontal resolution of $0.9^{\circ} \times 1.25^{\circ}, 56$ hybrid sigma pressure levels and configured in the "specified dynamics" mode (Lin, 2004; Neale et al., 2004). This resolution allowed us to constrain the model-simulated meteorology to match with the meteorological analysis from MERRA-2. The meteorology prescribed in the model include winds, temperature, surface heat, and moisture fluxes. The clouds and aerosols are allowed to evolve according to the model's governing equations (Ma et al., 2015; Tilmes et al., 2015). The CAM5.3 uses a modal approach to represent the aerosol life cycle in a way such that different aerosol species are internally mixed within modes and externally mixed between modes (Ghan et al., 2012; Liu et al., 2012). The 3-mode version of the modal aerosol module (MAM3) used in this study provides internally mixed representations of number and mass size distributions for Aitken-, accumulation- and coarse-mode aerosols. Aitken-mode species include sulfate, secondary organic aerosol (SOA), and sea salt. Accumulation-mode species include sulfate, SOA, BC, primary organic matter (POM), sea salt, and dust, while coarse-mode species include sea salt, dust, and sulfate. The model consists of all the key processes influencing the aerosol life cycle, such as precursor gas and particle emissions, gas- and aqueous-phase chemistry, nucleation, condensation, coagulation, aging, precipitation scavenging, and dry deposition (Liu et al., 2012). In CAM5, the Rapid Radiative Transfer Method for GCMs (RRTMG) used to calculate the long and shortwave radiative transfer (Iacono et al., 2008). The aerosol optical properties for each internally mixed modes of MAM defined according to Ghan and Zaveri (2007).

The model simulations are performed from 1 December 2009 to 31 December 2015, with the first one month of model output excluded from our analyses to allow the model to spin up following the initial conditions. We conduct two simulations with identical model configuration using prescribed greenhouse gas concentrations and anthropogenic emissions of aerosols and their precursors (Representative Concentration Pathway 8.5) as described by van Vuuren et al. (2011) and Lamarque et al. (2011), except, one using the $\mathrm{BC}$ emissions from on-road transportation sector within India as discussed in this work and the other one neglecting the $\mathrm{BC}$ emissions from on-road transportation sector in India. The default emissions of carbonaceous aerosols (BC and $\mathrm{OC}$ ) from the road transportation sector in the emission inventories corresponding to RCP 8.5 scenario is replaced by the new local emission inventory developed as part of the present study for emissions within India and merged with the global emission inventory described by Lamarque et al. (2011) and van Vuuren et al. (2011). In this study, we have analyzed six years (1 January-31 December of 2010-2015) of monthly mean simulated data of aerosol and radiative fluxes to estimate the DRF due to $\mathrm{BC}$ emissions from the onroad transportation sector in India.

\section{Calculation of Aerosol Radiative Forcing}

We followed the IPCC AR5 (The Intergovernmental Panel on Climate Change Fifth Assessment Report) methodology for estimating the anthropogenic aerosol effects on the planetary energy balance in terms of effective radiative forcing (ERF) that allows clouds to respond to aerosol while surface temperature prescribed. This method allows us to quantify aerosol radiative effects in terms of effective radiative forcing from aerosol-radiation interactions (ARI) as well as from aerosol-cloud interactions (ACI). However, it is worth mentioning here that although constraining the model meteorology to match with the meteorological analysis from MERRA-2 has several advantages such as it facilitates direct comparisons between model simulations and observations at specific times and locations, one limitation of this approach is that it removes the aerosol-induced feedbacks to the atmospheric dynamics and the constrained temperature eliminates the semi-direct effects of aerosols (Ma et al., 2015; Tilmes et al., 2015). Hence, in this study, we restrict our discussion to effective radiative forcing from aerosol-radiation interactions alone, which is also known in conventional terms as the aerosol direct radiative forcing.

Our calculations of aerosol direct radiative forcing are based on the work of Ghan et al. (2012) and Ghan (2013). The BC aerosol DRF discussed here is defined as roadtransportation-sector-induced changes in radiative fluxes at the TOA and at the surface, calculated as the difference of radiative fluxes at the desired level between simulations with and without $\mathrm{BC}$ emissions from on-road transportation 
sector in India (denoted by $\boldsymbol{\Delta}$ ). In each simulation, aerosol forcing defined as the difference between all-sky and cleansky radiative fluxes ( $\mathrm{F}-$ Fclean), where $F$ is the radiative flux under all-sky conditions and Fclean is the radiative flux calculated as a diagnostic from the same simulation, but neglecting the scattering and absorption of solar radiation by aerosols. Thus, in the present study, aerosol direct radiative forcing is estimated as $\Delta(\mathrm{F}-\mathrm{Fclean})$. The difference of the forcing values at the TOA and surface is further used to estimate the energy trapped within the atmosphere due to BC emissions from the road transportation sector.

As discussed later, in Section 3.3 that there is approximately $50 \%$ uncertainty in our emission estimates of $\mathrm{BC}$ from the road transportation sector in India. Hence, in order to understand how this uncertainty in the emissions of $\mathrm{BC}$ from the road transportation sector in India translates into uncertainty in DRF estimates, we carry out two more model sensitivity experiments in addition to the pair of standard simulations described earlier. These sensitivity experiments are identical to the simulation setup discussed earlier for the case which included the $\mathrm{BC}$ emissions from on-road transportation sector within India, except in one case we increased the gridded $\mathrm{BC}$ emissions from the road transportation sector in India by $50 \%$ and in the other case, we decreased the same emissions by $50 \%$ of the mean value used earlier, while the $\mathrm{BC}$ emissions outside India and across the world remained same in all our experiments.

\section{RESULTS AND DISCUSSION}

\section{Emission Factors of PM2.5 and Carbonaceous Aerosol \\ Emission Factors of Non-super-emitter Vehicles}

Table 1 shows the EFs of $\mathrm{PM}_{2.5}$ and carbonaceous aerosols (BC and $\mathrm{OC}$ ) for non-super-emitter vehicles classified in terms of thirteen different vehicle categories, three different fuel types, and three different age groups namely, A (2010 2013), B (2006-2009) and C (2001-2005). The measured on-road EFs of 4W-diesel, 4W-gasoline, 4W-CNG, 2W-4S, and LMV-passenger emphasized as in bold are taken from our companion paper (Table 1). The other EFs factors mentioned in Table 1 compiled from the previous literature, which measured from controlled laboratory condition.

The average $\mathrm{PM}_{2.5}$ EFs of non-super-emitter dieselpowered vehicles (Table 1 and Fig. S2) is found to be lowest $\left(1.1 \pm 0.2 \mathrm{~g} \mathrm{~kg}^{-1}\right)$ for "other" type (tractor and trailer) and highest for LMV-goods (4Ws; $11.2 \pm 7.0 \mathrm{~g} \mathrm{~kg}^{-1}$ ) of Age Group C (2001-2005). As evident from Table 1 that $\mathrm{PM}_{2.5}$ EFs increase by a factor of 2-5 with increasing vehicle age for most vehicle categories. In contrast the results also showed that the $\mathrm{PM}_{2.5}$ EF for $4 \mathrm{~W}$-diesel of the model year 2001-2005 (C) is lower than the EFs for Age Groups A and B. Vehicles older than 10 years of age are not readily available in Delhi and hence, the measurements could not be repeated for more vehicles to confirm this trend. A previous study by Alves et al. (2015) also reported lower EFs from well-maintained old vehicles compared to poorly maintained and rigorously used newer vehicles. Besides, we also noted that the EF reported by ARAI (2008) for Indian vehicles of the same age group (C) was close to the values measured by us. Therefore, we used the emission factor for 4-W diesel on-road from measurement even though it was contrary to the trend.

The EFs of super-emitter vehicles (Table 2 and Fig. S2) are a factor of 2-17 times higher than non-super-emitter category. Super-emitters characterized by their low contribution ( $\sim 24 \%)$ to traffic volume but high contribution (over 50\%) to emissions. The relationship between the traffic volume and emissions from non-super-emitter and super-emitter vehicles discussed in later section.

We compare the EFs used in previous global, national, and regional emission estimates with the values used in present work (Fig. 1). It is noteworthy that the emission factors used in present work are within the range of values used in previous emission estimates. In some case considerable difference in present and previous work (Sahu et al., 2008; Lu et al., 2011) arose because either earlier studies have compiled emission factors for few vehicle categories from dynamometer study or derived from emission models (Broken et al., 2007; Ohara et al., 2007; Klimont et al., 2009; Zhang et al., 2009). Therefore, in the present work, we used onroad EFs from the present study for $4 \mathrm{~W}$-passenger cars and did not average them with values reported in the literature from dynamometer study and emission models. The emission factors for other categories in which the on-road emission measurement not done in present work, the values from the literature averaged for emission calculation. Therefore, measured EFs is our motivation in this work to understand the impact on total emission and climate forcing.

\section{Vehicle Traffic Volume and Fuel Use Estimate}

The vehicle traffic volume (billion vehicles) which is the product of on-road vehicle population and annual distance travel was highest for $2 \mathrm{~W}$-gasoline ( $56 \%$ of 1550 billion vehicle $\mathrm{km}$ ) followed by diesel-powered "other vehicles", HDV, LMV-goods, passenger and buses, while CNG vehicles contribute the smallest fraction of total traffic volume (Figs. 2(a)-(c)). However, one can notice that fuel use showed the opposite trend as diesel fuel consumption by "other vehicles" and HDV-trucks was higher as compared to 2W-gasoline and CNG vehicles (Figs. 2(d)-2(f)), because of lower (4-10 times) fuel economy of diesel vehicles (Table S2) compared to $2 \mathrm{~W}$ gasoline-powered vehicles.

\section{Emissions Estimates of PM2.5 and Carbonaceous Aerosol}

The central value and $95 \%$ confidence interval (CI) of $\mathrm{PM}_{2.5}$ emissions from on-road transport sector is estimated to be around 355 (104-607) $\mathrm{Gg} \mathrm{y}^{-1}$ at the national level with maximum contribution from diesel vehicles (83.7\%) followed by gasoline (15.6\%), and an insignificant contribution from CNG (0.7\%) (Fig. 3). Although, diesel vehicles comprise only $27 \%$ (416 billion vehicle $\mathrm{km}$ ) of total traffic volume (1550 billion vehicle $\mathrm{km}$ ) (Fig. 3), gasoline and CNG contributes rest $73 \%$; however, low fuel economy and high EFs (Tables 1 and S2) of diesel vehicles and more than 2 times higher fuel consumption $\left(52 \mathrm{MT} \mathrm{y}^{-1}\right)$ resulted in 5.3 times higher emissions (297 $\left.\mathrm{Gg} \mathrm{y}^{-1}\right)$ compared to gasoline vehicles. Interestingly, non-super-emitter and super-emitter vehicle comprise $76 \%$ and $24 \%$ of the total traffic volume, 
Table 2. Emission factors of $\mathrm{PM}_{2.5}, \mathrm{BC}$, and $\mathrm{OC}$ for super-emitter vehicles.

\begin{tabular}{|c|c|c|c|}
\hline \multirow{2}{*}{ Vehicle type } & \multicolumn{3}{|c|}{ Aerosol and its constituents $\left(\mathrm{g} \mathrm{kg}^{-1}\right)$} \\
\hline & $\mathrm{PM}_{2.5}$ & $\mathrm{BC}$ & $\mathrm{OC}$ \\
\hline \multicolumn{4}{|l|}{ Diesel } \\
\hline LMV-goods (3W) & $27.5(22.4-33.8)^{\mathrm{a}, \mathrm{b}}$ & $(15.1 \pm 14.8)^{*}$ & $(5.5 \pm 5.4)^{*}$ \\
\hline LMV-goods (4W) & $(26.2 \pm 25.6)^{\mathrm{a}-\mathrm{d}}$ & $(14.4 \pm 14.1)^{*}$ & $(5.1 \pm 5.9)^{\mathrm{a}, \mathrm{c}, \mathrm{d}}$ \\
\hline Passenger car & $(11.1 \pm 7.4)^{\mathrm{a}-\mathrm{e}}$ & $(5.0 \pm 1.8)^{\mathrm{c}, \mathrm{d}, \mathrm{e}}$ & $(2.0 \pm 0.7)^{\mathrm{a}, \mathrm{c}, \mathrm{d}, \mathrm{e}}$ \\
\hline HDV & $(18.4 \pm 13.1)^{\mathrm{a}-\mathrm{d}}$ & $(6.6 \pm 6.5)^{d}$ & $(3.9 \pm 3.1)^{\mathrm{a}, \mathrm{c}, \mathrm{d}}$ \\
\hline Bus & $(17.9 \pm 12.1)^{\mathrm{a}-\mathrm{d}}$ & $(4.9 \pm 1.6)^{\mathrm{a}, \mathrm{c}, \mathrm{d}}$ & $(3.9 \pm 3.1)^{\mathrm{a}, \mathrm{c}, \mathrm{d}}$ \\
\hline Other & $(18.7 \pm 13.6)^{\mathrm{a}-\mathrm{d}}$ & $(4.9 \pm 1.6)^{\mathrm{a}, \mathrm{c}, \mathrm{d}}$ & $(3.9 \pm 3.1)^{\mathrm{a}, \mathrm{c}, \mathrm{d}}$ \\
\hline \multicolumn{4}{|l|}{ Gasoline } \\
\hline 2-wheeler (2S) & $(22.9 \pm 6.2)^{\mathrm{a}, \mathrm{b}, \mathrm{d}}$ & $1.2(1.0-1.5)^{\mathrm{a}, \mathrm{b}}$ & $16.1(11.0-23.7)^{\mathrm{a}, \mathrm{b}}$ \\
\hline 2-wheeler (4S) & $3.6(3.2-4.0)^{\mathrm{a}, \mathrm{b}}$ & $(0.2 \pm 0.2)^{\mathrm{a}}$ & $(2.2 \pm 1.1)^{\mathrm{a}}$ \\
\hline LMV-passenger (3W) & $(4.8 \pm 1.0)^{\mathrm{a}, \mathrm{b}, \mathrm{f}}$ & $0.7(0.2-2.2)^{\mathrm{a}, \mathrm{f}}$ & $2.7(2.4-2.9)^{\mathrm{a}, \mathrm{f}}$ \\
\hline Passenger car & $(2.6 \pm 1.7)^{\mathrm{a}, \mathrm{b}, \mathrm{d}, \mathrm{e}}$ & $(0.6 \pm 0.5)^{\mathrm{a}, \mathrm{d}, \mathrm{e}}$ & $0.9(0.7-1.1)^{\mathrm{a}, \mathrm{f}}$ \\
\hline \multicolumn{4}{|l|}{ CNG } \\
\hline LMV-passenger (3W) & $8.6(4.6-15.9)^{\mathrm{a}, \mathrm{f}}$ & $1.2(0.9-1.6)^{\mathrm{a}, \mathrm{f}}$ & $4.7(2.3-9.5)^{\mathrm{a}, \mathrm{f}}$ \\
\hline Passenger car & $(2.5 \pm 2.5)^{b}$ & $(0.8 \pm 0.7)^{*}$ & $(0.9 \pm 0.8)^{*}$ \\
\hline Bus & $(2.0 \pm 2.0)^{\mathrm{b}}$ & $(0.3 \pm 0.3)^{*}$ & $(0.9 \pm 0.9)^{*}$ \\
\hline
\end{tabular}

For three emission factor (EF) values averaged from following literature. Values in parentheses indicate standard deviation. If literature reported only two EF values, then we calculate geometric mean. Value in parentheses represent lower and upper range of EFs from literature.

* Average fraction of $\mathrm{BC} / \mathrm{PM}_{2.5}$ and $\mathrm{OC} / \mathrm{PM}_{2.5}$ were reported in Bond et al. (2004) and ARAI (2008, 2009).

a Old-vintage (before 2000) EFs were compiled for $\mathrm{PM}_{2.5}$ from ARAI $(2008,2009)$.

${ }^{\mathrm{b}}$ Based on COPERT-modeled $\mathrm{PM}_{2.5}$ emission factors from Goel and Guttikunda (2015).

${ }^{c}$ Based on dynamometer measurement for 33 light-duty vehicles from Subramanian et al. (2009).

d Based on opacity-based measurement for "smoker" gasoline, diesel, and farm/non-farm vehicles from Bond et al. (2004).

${ }^{\mathrm{e}}$ Based on chassis dynamometer and opacity measurement for 4-wheeler gasoline and diesel vehicles from Yan et al. (2011).

${ }^{\mathrm{f}}$ From Grieshop et al. (2012): (29) 3-wheelers (10 petrol and $19 \mathrm{CNG}$ ) were measured on chassis dynamometer studies.

respectively but contribute $33 \%\left(119[77-161] \mathrm{Gg} \mathrm{y}^{-1}\right)$ and $67 \%$ (236 [27-446] $\left.\mathrm{Gg} \mathrm{y}^{-1}\right)$ of total national-level $\mathrm{PM}_{2.5}$ emissions (Fig. 3). This implies that the vehicle growth in future and fraction of super-emitters can significantly intensify the $\mathrm{PM}_{2.5}$ emissions from the on-road transport sector. Therefore, a proper mitigation policy must not only focus on strengthening public transport as an emission reduction option but also should focus on controlling the fraction of super-emitters. It is worth noting that the uncertainty associated with emission estimates from the super-emitter vehicles $(89 \%)$ is significantly higher than non-super-emitter vehicle category $(36 \%)$ because the EFs for super-emitters not assessed yet and their exact fraction in terms of traffic volume is also not known.

It is important to note here that although the HDV-trucks and "other vehicles" (tractor/trailer) have a relatively smaller contribution (7-8\%) towards the total traffic volume (Fig. 2(a)), these vehicles contribute significantly (55\%) towards the national $\mathrm{PM}_{2.5}$ emissions from India with almost equal contributions from HDV-trucks $\left(28 \%\left(99 \mathrm{Gg} \mathrm{y}^{-1}\right)\right.$ and "other vehicles" (tractor/trailer; 27\% (97 Gg y $\left.{ }^{-1}\right)$ ). On the other hand, the LMV-goods vehicles with 3 times higher EFs and much lower share towards the on-road traffic volume $(5 \%)$ contribute nearly $12 \%$ of the national $\mathrm{PM}_{2.5}$ emissions from India. With economic growth and rapid urbanization happening across India, the on-road traffic volume of freight (i.e., "other vehicles", LMV-goods, and HDV-trucks) is expected to increase rapidly in the coming years and hence a mechanism of on-road measurement of emission profile for this category vehicles are crucial for quantifying their correct contribution towards the total national emission of $\mathrm{PM}_{2.5}$ and climate forcing agents like carbonaceous aerosols from India. Diesel-powered public transport (buses), and private cars ( $4 \mathrm{Ws}$ ) contribute only $2 \%$ and 5\% towards the total on-road traffic volume but contribute nearly $9 \%\left(44 \mathrm{Gg} \mathrm{y}^{-1}\right)$ and $7 \%\left(26 \mathrm{Gg} \mathrm{y}^{-1}\right)$ towards the national $\mathrm{PM}_{2.5}$ emissions (Fig. 3(a)). The contribution from non-super-emitters and super-emitter vehicles among the diesel-powered high-emitting technologies to the total $\mathrm{PM}_{2.5}$ emissions across India estimated as $34 \%\left(33.7 \mathrm{Gg} \mathrm{y}^{-1}\right)$ and $66 \%\left(65.3 \mathrm{Gg} \mathrm{y}^{-1}\right)$ respectively for HDVs, $80 \%\left(77.8 \mathrm{Gg} \mathrm{y}^{-1}\right)$ and $20 \%\left(19.4 \mathrm{Gg} \mathrm{y}^{-1}\right)$ respectively for "others" and $45 \%$ $\left(19.3 \mathrm{Gg} \mathrm{y}^{-1}\right)$ and $55 \%\left(24 \mathrm{Gg} \mathrm{y}^{-1}\right)$ respectively for LMVgoods vehicles (Fig. 3(a)).

Our results further show that the gasoline-powered $2 \mathrm{Ws}$, LMV-passengers, and 4W-passenger cars contribute nominally $10 \%\left(36.5 \mathrm{Gg} \mathrm{y}^{-1}\right), 3 \%\left(10.4 \mathrm{Gg} \mathrm{y}^{-1}\right)$ and $2 \%\left(8.7 \mathrm{Gg} \mathrm{y}^{-1}\right)$ respectively to national-level $\mathrm{PM}_{2.5}$ estimates (Fig. 3(b)). It is worth noting here that even though $2 \mathrm{~W}$ vehicles have a maximum contribution towards the on-road traffic volume (56\% of 1150 billion vehicle $\mathrm{km}$ ) but contribute only $10 \%$ towards the national $\mathrm{PM}_{2.5}$ emissions and this is mainly due to low fuel consumption and low EFs reported for $2 \mathrm{Ws}$. The contribution of gasoline-powered non-super-emitter and super-emitter vehicles in different categories towards the total $\mathrm{PM}_{2.5}$ emissions $\left(56 \mathrm{Gg} \mathrm{y}^{-1}\right)$ estimated as $19.6 \%\left(11 \mathrm{Gg} \mathrm{y}^{-1}\right)$ 

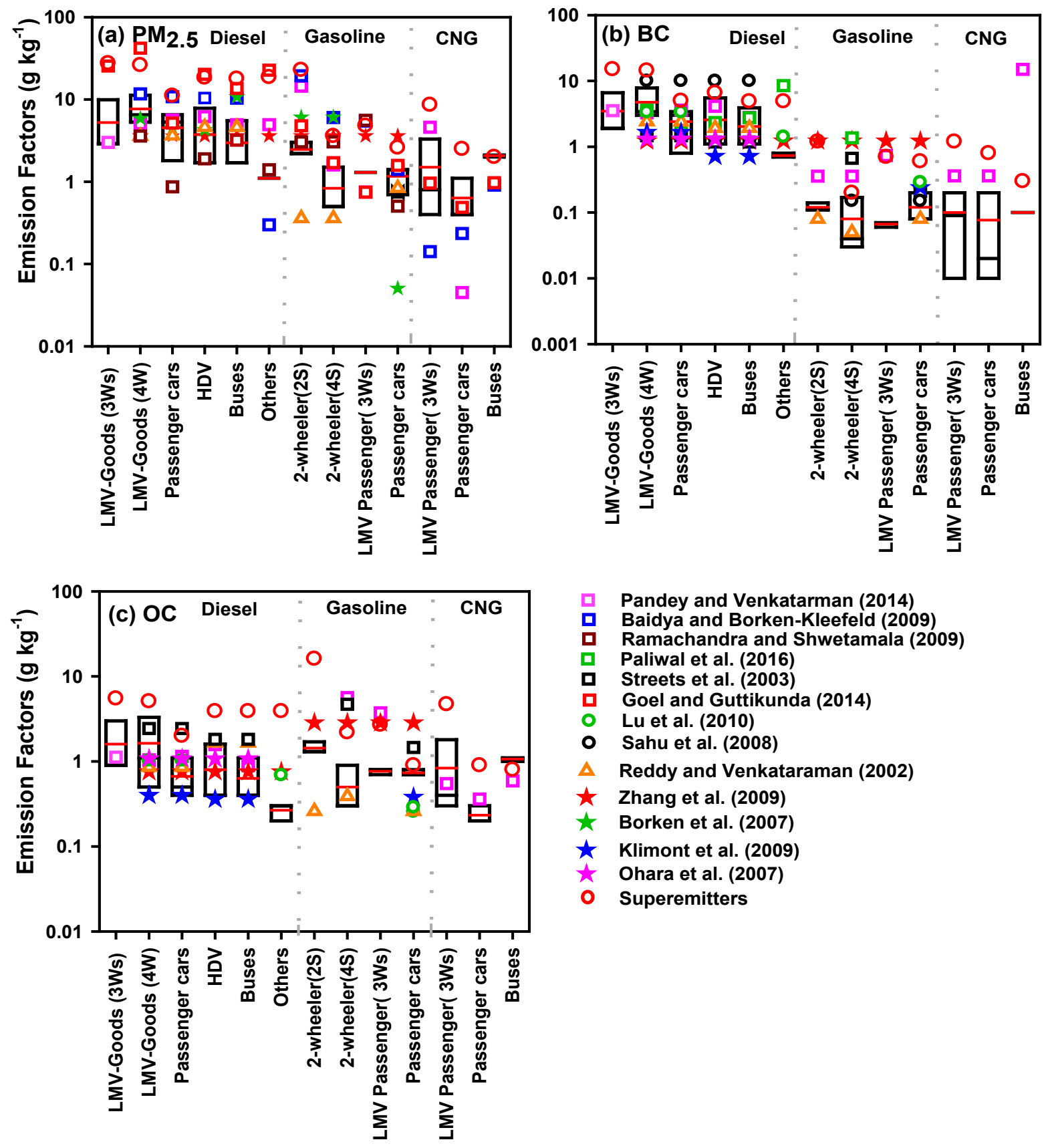

Fig. 1. Variation of EFs using emission estimate of previous and comparison with present study. Open square legends ( $\square$ ) correspond to estimates from previous studies which used category-wise vehicular EFs. Open circle (O) indicates the EFs adopted by earlier literature for few vehicle category and applied to national level emission estimate. Star ( $\star$ ) symbol corresponds to results from emission models and derived EFs.Open red circle indicates the EFs of super-emitter vehicles. The super-emitter vehicles were compiled from the previous studies (Bond et al., 2004; ARAI, 2008, 2009; Subramanian et al., 2009; Sadavarte and Venkataraman, 2014; Goel and Guttikunda, 2015).

and $46.4 \%\left(26 \mathrm{Gg} \mathrm{y}^{-1}\right)$ for $2 \mathrm{Ws}, 6.4 \%\left(3.6 \mathrm{Gg} \mathrm{y}^{-1}\right)$ and $12.1 \%$ $\left(6.8 \mathrm{Gg} \mathrm{y}^{-1}\right)$ for LMV-passenger, and $8.7 \%\left(4.9 \mathrm{Gg} \mathrm{y}^{-1}\right)$ and $6.8 \%\left(3.8 \mathrm{Gg} \mathrm{y}^{-1}\right)$ for passenger cars respectively (Fig. 3(b)). The contributions from CNG-operated non-super-emitter and super-emitter vehicles towards the total $\mathrm{PM}_{2.5}$ emissions $\left(2.4 \mathrm{Gg} \mathrm{y}^{-1}\right)$ estimated as $25 \% \quad\left(0.6 \mathrm{Gg} \mathrm{y}^{-1}\right)$ and $50 \%$ $\left(1.2 \mathrm{Gg} \mathrm{y}^{-1}\right)$ respectively for LMV-passenger ( $\left.3 \mathrm{~W}\right)$ vehicles (Fig. 3(c)) and the remaining $25 \%$ of $\mathrm{PM}_{2.5}$ emissions from
CNG-powered vehicles are contributed by CNG passenger cars and buses with higher contribution once again from super-emitter vehicles in this category. Thus overall, the super-emitter vehicles contribute more than $50 \%$ of $\mathrm{PM}_{2.5}$ emissions from all vehicle categories in India.

Results of present study suggests that the total BC emissions from on-road transport sector at the national level is around 137 (47-227) $\mathrm{Gg} \mathrm{y}^{-1}$ with maximum contribution 

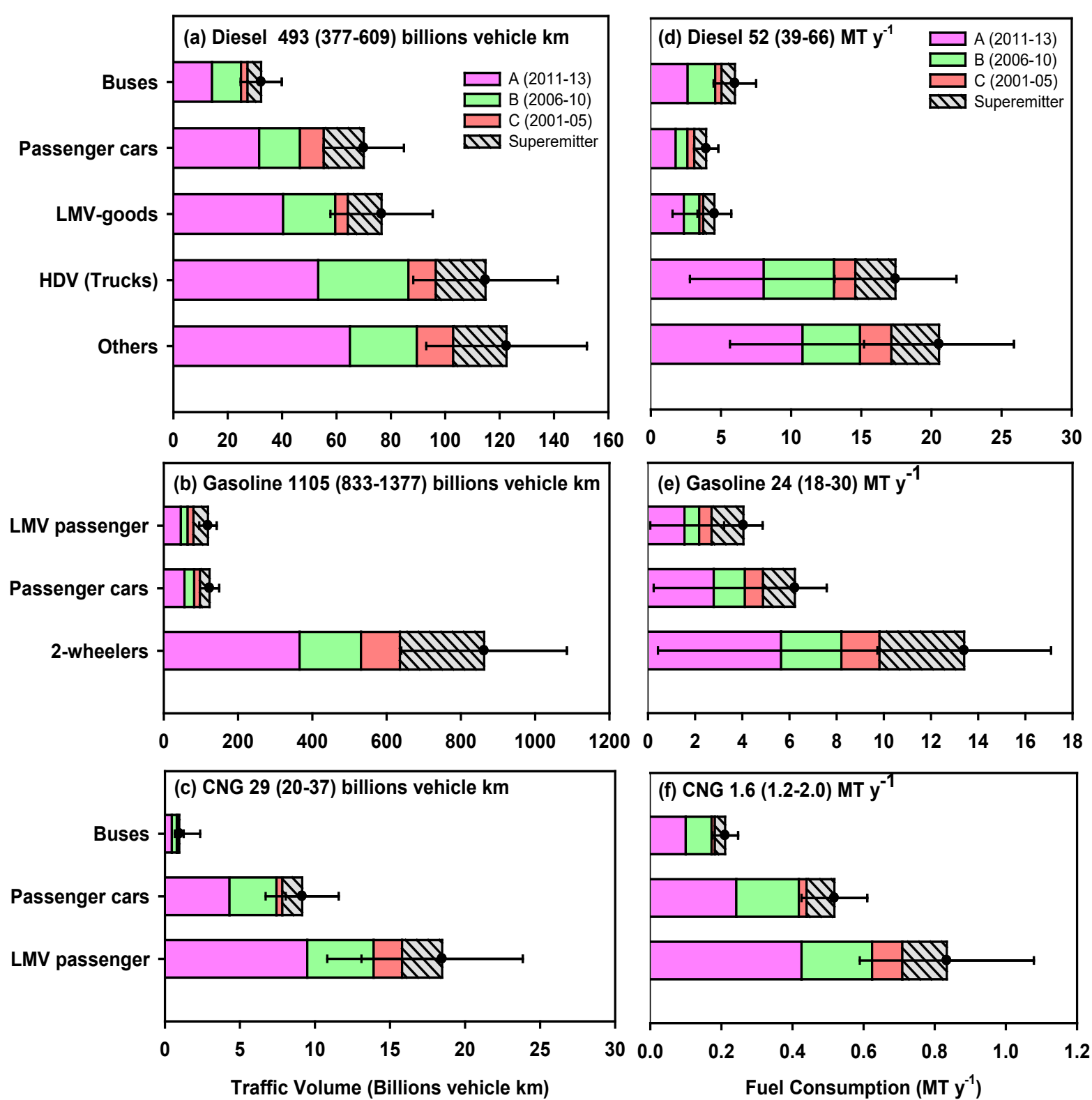

Fig. 2. Estimated total traffic volume (left panel) and fuel consumption (right panel) from on-road transport sector.

from diesel-powered vehicles $\left(96 \%, 131 \mathrm{Gg} \mathrm{y}^{-1}\right)$ and much smaller contribution $\left(4 \%, 6 \mathrm{Gg} \mathrm{y}^{-1}\right)$ from gasoline- and CNGpowered vehicles (Figs. 3(d)-3(f)). Overall super-emitters and non-super-emitters contribute nearly 53\% (72 [5-139] Gg $\left.\mathrm{y}^{-1}\right)$ and $47 \%\left(64[42-88] \mathrm{Gg} \mathrm{y}^{-1}\right)$ respectively of total $\mathrm{BC}$ emissions from on-road transport sector. However, considerable uncertainty of nearly $92 \%$ and $36 \%$ are associated with our estimates of $\mathrm{BC}$ emissions from super-emitters and non-superemitter vehicles, respectively. Most remarkably our estimates of $\mathrm{BC}$ emissions from on-road transport sector suggests that among the super-emitter vehicles, an overwhelming majority $\left(94 \%\left(68 \mathrm{Gg} \mathrm{y}^{-1}\right)\right)$ of BC emissions contributed by dieselpowered vehicles and only a small fraction $\left(6 \%\left(4 \mathrm{Gg} \mathrm{y}^{-1}\right)\right)$ comes from gasoline and $\mathrm{CNG}$ vehicles. Our results further suggest that while the overall contribution of non-superemitter vehicles is around $47 \%$ towards the total nationallevel BC emissions from on-road transport sector, the diesel-, gasoline-, and CNG-powered non-super-emitter vehicles contribute nearly $46.2 \%\left(63 \mathrm{Gg} \mathrm{y}^{-1}\right), 0.96 \%\left(1 \mathrm{Gg} \mathrm{y}^{-1}\right)$ and $0.03 \%\left(0.05 \mathrm{Gg} \mathrm{y}^{-1}\right)$, respectively. Among vehicle categories, HDV-trucks account for the highest 34\% (46.3 $\left.\mathrm{Gg} \mathrm{y}^{-1}\right)$ contribution to the total BC, followed by "other vehicles" at $24 \%\left(33 \mathrm{Gg} \mathrm{y}^{-1}\right)$, LMV-goods at $18 \%\left(24.7 \mathrm{Gg} \mathrm{y}^{-1}\right)$, passenger cars at $11 \%\left(15 \mathrm{Gg} \mathrm{y}^{-1}\right)$, buses at $9 \%\left(12.3 \mathrm{Gg} \mathrm{y}^{-1}\right)$, 2-wheeler at $2 \%\left(2.7 \mathrm{Gg} \mathrm{y}^{-1}\right)$ and LMV-passenger at $1 \%\left(1.4 \mathrm{Gg} \mathrm{y}^{-1}\right)$. Overall, the contribution of commercial freight vehicles and passenger vehicles estimated around $76 \%$ and $24 \%$ respectively to the total national-level $\mathrm{BC}$ emissions from the on-road transport sector.

Furthermore, the total OC emissions from on-road transport sector at national level estimated as $106(34-178) \mathrm{Gg} \mathrm{y}^{-1}$ with leading contribution from diesel vehicles $(58 \%, 61$ [15111] $\left.\mathrm{Gg} \mathrm{y}^{-1}\right)$ followed by gasoline $\left(41 \%, 43\right.$ [22-64] $\left.\mathrm{Gg} \mathrm{y}^{-1}\right)$, and CNG-powered vehicles $\left(1 \%, 1.3 \mathrm{Gg} \mathrm{y}^{-1}\right)$ (Figs. 3(g)-3(i)). 

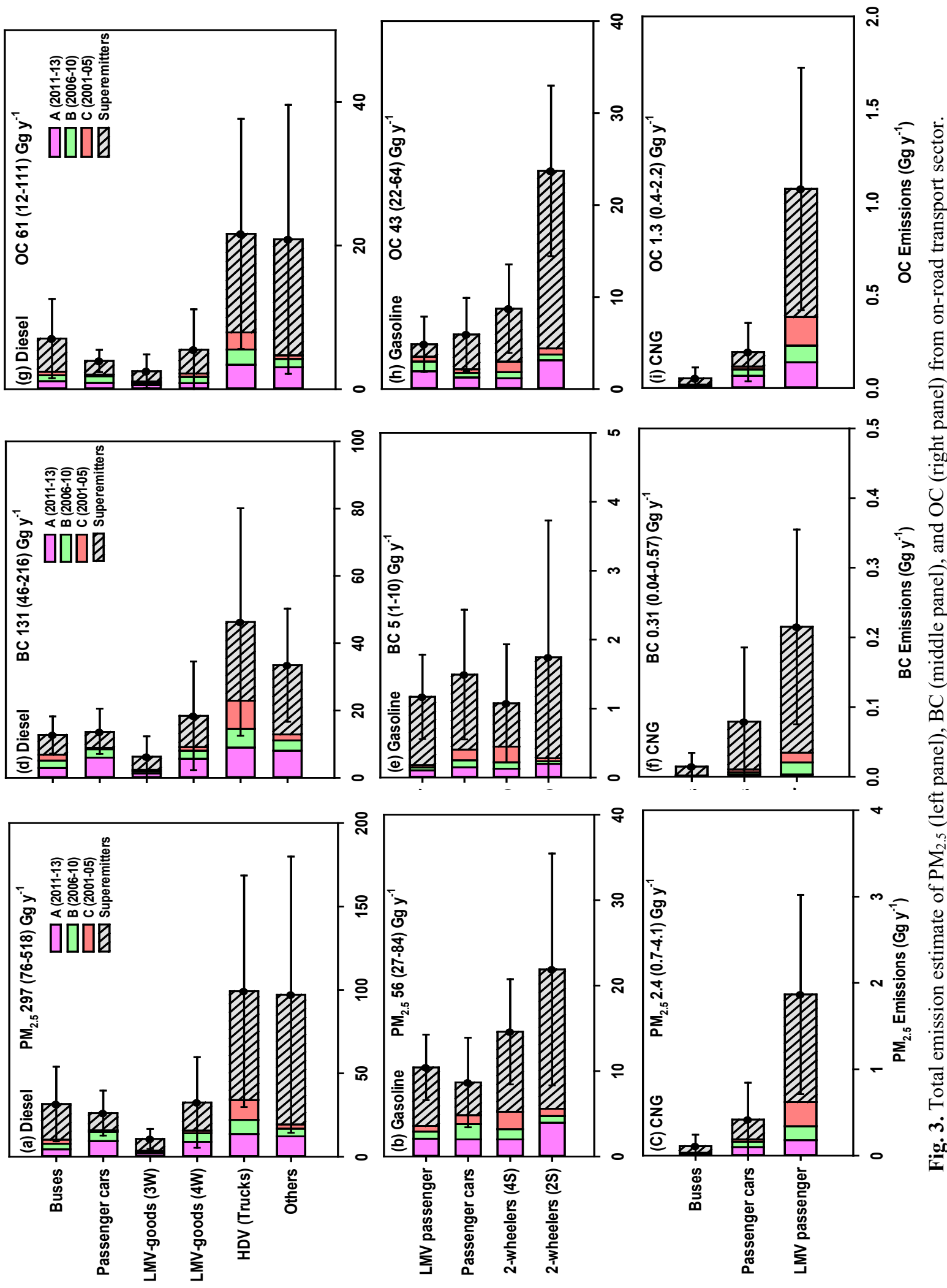
In terms of vehicle category among diesel-powered vehicles, HDVs emit highest OC $\left(20 \%, 22 \mathrm{Gg} \mathrm{y}^{-1}\right)$, followed by "other vehicles" $\left(20 \%, 21 \mathrm{Gg} \mathrm{y}^{-1}\right)$, LMV-goods $\left(7 \%, 7 \mathrm{Gg} \mathrm{y}^{-1}\right)$, buses $\left(7 \%, 7 \mathrm{Gg}^{-1}\right)$, and passenger cars $\left(4 \%, 4 \mathrm{Gg} \mathrm{y}^{-1}\right)$. Among gasoline vehicles, 2-wheelers are found to be the highest emitter of OC $\left(75 \%, 32 \mathrm{Gg} \mathrm{y}^{-1}\right)$, while LMV-passenger and passenger cars contribute $14 \%\left(14.8 \mathrm{Gg} \mathrm{y}^{-1}\right)$ and $11 \%$ $\left(11.7 \mathrm{Gg} \mathrm{y}^{-1}\right)$ respectively towards the total OC emissions. Overall passenger vehicles (i.e., 2Ws, LMV-passenger, 4Ws, and buses) and commercial freight vehicles (i.e., HDVtrucks, LMV-goods, "others") contribute almost equally (52\% and $48 \%$ respectively) towards the total OC emissions at the national level from on-road transport sector. Non-superemitters and super-emitters contribute nearly $32 \%\left(34 \mathrm{Gg} \mathrm{y}^{-1}\right)$ and $68 \%\left(72 \mathrm{Gg} \mathrm{y}^{-1}\right)$ respectively of the total $\mathrm{OC}$ emissions from this sector. The uncertainty associated with the estimates of OC emission with $95 \%$ CI is calculated to be $79 \%$ and $43 \%$ for super-emitters and for non-super-emitter vehicles respectively.

Thus, our findings from the present study emphasize the need for emission control from the on-road transport sector in India. In fact, keeping in view the expected growth of road transport sector in India, our study suggests that the contribution of super-emitters and non-super-emitters needs to be ascertained more accurately by making the correct measurements of emissions from all kinds of vehicles under real-world driving pattern prevalent in India. Besides emission measurement, a compilation of activity data such as on-road vehicle population, vehicle lifetime, annual distance travel, and mileage is a necessity, should be collected across the country.

\section{Comparison with Previous Emission Estimate}

Fig. S3 presents the comparison of emissions of $\mathrm{PM}_{2.5}$, $\mathrm{BC}$, and OC for the base year 2013 as estimated in the present study with previous emission estimates reported for the base year anywhere between the period 2000-2010. For making this comparison, we scaled the previous emission estimates by multiplying them with the ratio of present-day fuel usage to previously reported fuel usage. Our comparison shows that the $\mathrm{PM}_{2.5}$ emission estimated in the present study is comparable to recently reported emission estimates by Guttikunda and Mohan (2014), and Pandey and Venkataraman (2014) from the on-road transport sector for the same base year 2013 (Fig. S3). Higher values of EFs used in previous studies by Broken et al. (2007), Baidya and Borken-Kleefeld (2009) and Zhang et al. (2009) for most vehicle categories (Fig. S3(a)) resulted in approximately 17\%, 28\% and 29\% higher emission estimates respectively as compared to the present work. Lower values of EFs used by Reddy and Venkataraman (2002) and Ramachandra and Shewtmala (2009) for most vehicle categories as compared to our present work resulted in $23 \%$ and $37 \%$ lower emission estimates by these two studies respectively as compared to present work. The present estimates $\left(355 \mathrm{Gg} \mathrm{y}^{-1}\right.$ ) of $\mathrm{PM}_{2.5}$ emissions from on-road transport is 1.6 times higher than the estimate $\left(222 \mathrm{Gg} \mathrm{y}^{-1}\right)$ reported in Emissions Database for Global Atmospheric Research (EDGAR) (Crippa et al., 2018). However, most importantly, the uncertainty associated with the $\mathrm{PM}_{2.5}$ emission estimate from on-road transport sector with $95 \%$ CI reduced from $98 \%$ as reported in previous estimates by Pandey and Venkataraman (2014) to $70 \%$ in the present study.

We also compared our emission estimates with those reported for Delhi city by Goel and Guttikunda (2015) and Sharma and Dixshit (2016) by scaling the previous estimates for the base year 2013. Our estimate of $\mathrm{PM}_{2.5}$ emissions from 4-wheelers is 1.7 times higher than the values reported by Sharma and Dixshit (2016) and 1.8 times lower than values reported in Goel and Guttikunda (2015) for Delhi megacity. The difference is possibly because, Sharma and Dixshit (2016) used the EFs for all vehicle categories reported from chassis dynamometer measurements in ARAI $(2008,2009)$, which are lower than EFs determined from on-road measurement in the present work. On the other hand, the study by Goel and Guttikunda (2015) used fleet average (1999-2012) emission factor values derived from COPERT emission model, which could be higher than on-road measurement used in the present work.

BC emissions reported by Ohara et al. (2008) are 2.6-5.6 times higher than our estimates (Fig. S3(b)). Similarly, previous work by Street et al. (2003) and Sahu et al. (2008) have used higher BC EFs $\left(10 \mathrm{~g} \mathrm{~kg}^{-1}\right)$ for all categories of vehicles as compared to our present study. In the present work, BC EFs vary from low values of $0.7 \mathrm{~g} \mathrm{~kg}^{-1}$ for "other vehicles" to high values of $3.6 \mathrm{~g} \mathrm{~kg}^{-1}$ for passenger cars, and LMV-goods vehicles among the non-super-emitters (Age Group A and B), which comprise nearly $10 \%$ of the total vehicle population. The uncertainty at $95 \% \mathrm{CI}$ associated with $\mathrm{BC}$ emissions from on-road transport sector reduced from $105 \%$ as reported by Pandey and Venkataraman (2014) to $65 \%$ in the present work. The uncertainty in BC emissions as estimated in the present work is also consistent with the uncertainty reported by Paliwal et al. (2016) for the base year 2011.

$\mathrm{OC}$ emissions from on-road transport sector as estimated in the present work is mostly consistent (6-12\% difference) with the previous estimates reported by Pandey and Venkataraman (2014) and Guttikunda and Mohan (2014), while the present estimates are found to be $32-42 \%$ lower than the emissions reported by Reddy and Venkatarman (2002) and Ohara et al. (2007). Whereas some other previous studies such as by Klimont et al. (2009) and Lu et al. (2011) reported lower OC emissions compared to present estimates by $33 \%$ and $58 \%$ respectively (Fig. S3(c)). Our OC estimates are significantly lower (by 1.8-4.4 times) than the scaled emissions derived from the studies by Ohara et al. (2007), Zhang et al. (2009) and Street et al. (2013) (Fig. S3(c)), this could be attributed to the use of high EFs of LMV, HDV and 2-wheeler in previous studies. The uncertainty at $95 \% \mathrm{CI}$ associated with OC emissions from on-road transport sector reduced from $136 \%$ as reported by Pandey and Venkataraman (2014) to $95 \%$ in the present work.

Next, we compared the emission estimates of $\mathrm{PM}_{2.5}, \mathrm{BC}$ and $\mathrm{OC}$ from diesel- and gasoline-based 4-wheelers derived using different approaches such as EFs measured in on-road experiments as used in the present work, previous dynamometer studies, and emission models. Fig. 4 shows 
the analysis of national-level emission estimates of $\mathrm{PM}_{2.5}$, $\mathrm{BC}$ and $\mathrm{OC}$ from $4 \mathrm{Ws}$ due to the application of EFs from different approaches. The Student's $t$-test analysis showed the use of EFs measured from the on-road operation of 4wheelers resulted in significantly higher emissions $(\mathrm{p}<0.05$ at $95 \% \mathrm{CI}$ ) compared to those obtained using EFs from dynamometer study. For diesel-powered 4Ws the emission estimates of $\mathrm{PM}_{2.5}$ and $\mathrm{BC}$ using the EFs derived from $\mathrm{BC} / \mathrm{PM}_{2.5}$ ratios are slightly lower than the present estimates (Fig. 4), while for OC, model-derived EFs resulted in marginally higher emissions compared to present work. For gasoline-based 4-wheelers, the $\mathrm{PM}_{2.5}, \mathrm{BC}$, and $\mathrm{OC}$ emission estimates using model-derived emission factor are again marginally higher (7-18\%) compared to the present estimate (Fig. 4).

Thus the emission estimates based on model-derived EFs seem to be marginally different from the estimates of our present work, while estimates based on EFs from dynamometer are primarily lower than the present estimates. The EFs from on-road emission measurements used in the present work provide an intermediate well-bounded emission estimate.

\section{Spatial Distribution of Emission Fluxes}

The present emission estimates are then used to prepare a gridded emissions data $\left(0.25^{\circ} \times 0.25^{\circ}\right.$ resolution $)$ or spatial distribution of emission fluxes (tons grid ${ }^{-1} \mathrm{y}^{-1}$ ) of $\mathrm{PM}_{2.5}, \mathrm{BC}$, and $\mathrm{OC}$ from the Indian road transport sector for the base year 2013. Our gridded emissions data shows high emission fluxes with values greater than 1500 tons grid $^{-1} \mathrm{y}^{-1}$ of $\mathrm{PM}_{2.5}$ over the four metropolitan cities (Delhi, Mumbai, Kolkata, and Chennai) due to the high population, road density, and traffic volume (Fig. S4). The "golden quadrilateral" road network,
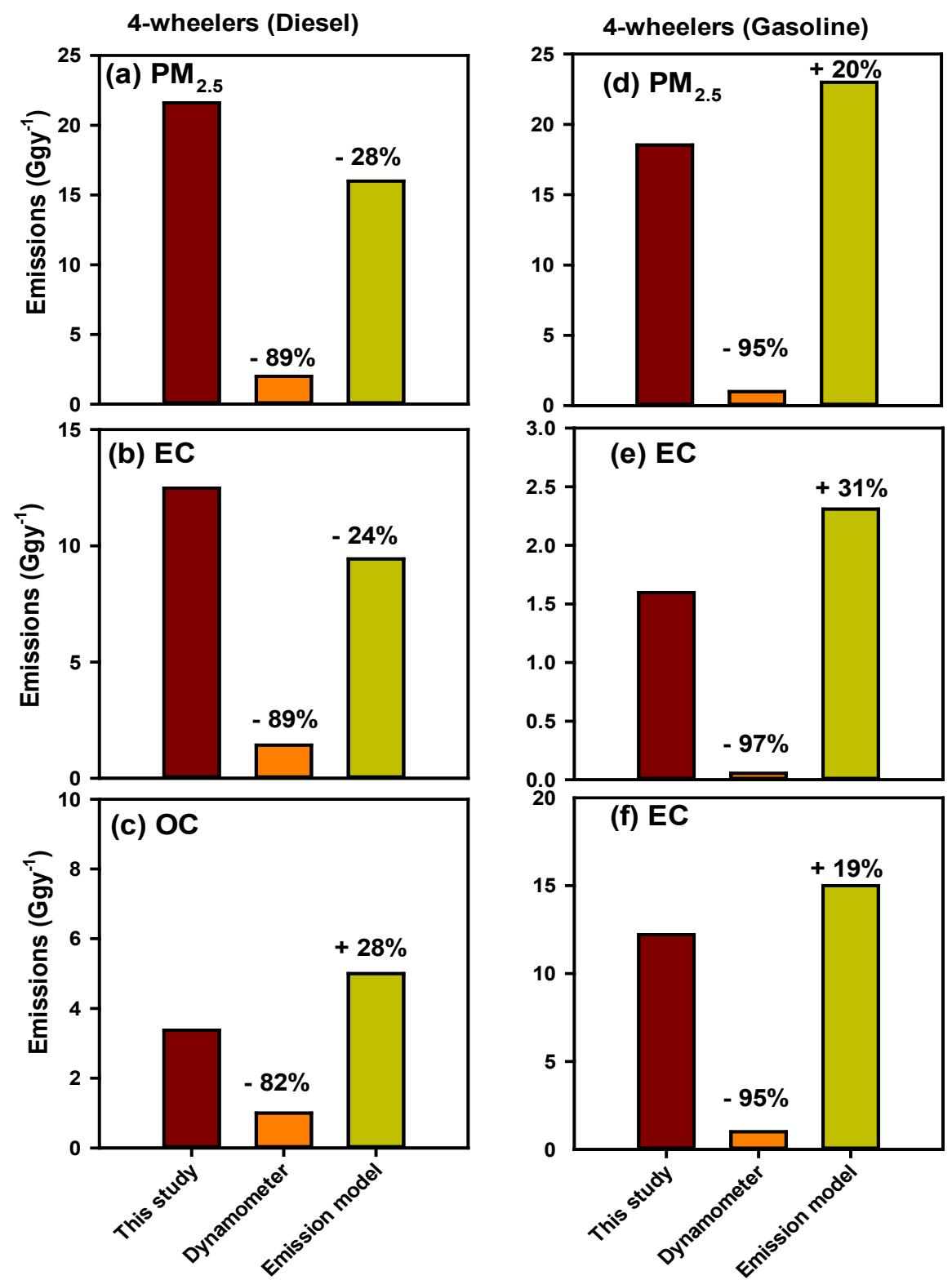

Fig. 4. Emission of $\mathrm{PM}_{2.5}, \mathrm{BC}$ and $\mathrm{OC}$ from 4-wheeler diesel and gasoline using on-road measured emission factors from the present work, dynamometer studies, and emission model. 
which connects the metro cities and industrial cluster showed a substantial magnitude of 500-1500 tons grid ${ }^{-1} \mathrm{y}^{-1}$ of $\mathrm{PM}_{2.5}$ emission fluxes. Industrial clusters within this road network are found to be associated with a moderate level of emissions ranging from 100 to 500 tons grid ${ }^{-1} \mathrm{y}^{-1}$ over the states of Gujarat, Maharashtra, Tamil Nadu, West Bengal, and Delhi, even though these states accounted $50 \%$ of $\mathrm{PM}_{2.5}$ emissions. The national and state highways showed $\mathrm{PM}_{2.5}$ emissions fluxes varying in the range of 100-500 tons grid ${ }^{-1} \mathrm{y}^{-1}$ from dieselpowered vehicles, whereas the entire district and urban grid emissions are found to vary from 5 to 100 tons grid $^{-1} \mathrm{y}^{-1}$ mainly due to gasoline and $\mathrm{CNG}$ vehicle emissions.

The gridded $\mathrm{BC}$ emissions showed a similar spatial variability as $\mathrm{PM}_{2.5}$ because $\mathrm{BC}$ is a dominant component of $\mathrm{PM}_{2.5}$ emissions from the on-road transport sector. Among vehicles, the primary source of $\mathrm{BC}$ is diesel-powered vehicles including LMV-goods, 4-wheeler diesel, HDVs, buses and tractor and trailers. The observed $\mathrm{BC}$ emission fluxes resemble road network density with higher values in Gujarat, Maharashtra, Tamil Nadu, West Bengal and Delhi (> 1000 tons grid $^{-1} \mathrm{y}^{-1}$ ) (Fig. S4, middle panel).

The clusters of OC emissions fluxes of magnitude $\geq 1500$ tons grid $^{-1} \mathrm{y}^{-1}$ noted over the Indo-Gangetic Plain (IGP) (Fig. S4, right panel), this is corroborated with dense population and demand of vehicles running on highefficiency fuels such as gasoline and $\mathrm{CNG}$, which emit more OC. The "golden quadrilateral" and national highways that are dominated by diesel vehicular traffic and related activities are also characterized by 50-1500 tons grid ${ }^{-1} \mathrm{y}^{-1}$ OC emission fluxes (Fig. S4, right panel). Interestingly, although the IGP region accounts for only $15 \%$ of the total Indian geographical area, this region accounts for nearly $42 \%\left(45 \mathrm{Gg} \mathrm{y}^{-1}\right)$ of the total $\mathrm{OC}$ emissions from the on-road transport sector in India. The remaining emissions (56\%) of OC distributed over central, northwestern, northern-eastern, and eastern part of central India, this is due to rapidly increasing urbanization in these parts of India that also increases the fuel demand for on-road transport sector in these regions.

To compare our spatially resolved emissions with previous work, we scaled the previous estimates for the different base year using the vehicle population growth rate reported by MORTH (2013). Overall we noted a good agreement between the emission estimates of the present work with the estimates earlier reported by Sadavarte and Venkataraman (2014) both in terms of magnitude and spatial distribution pattern of $\mathrm{PM}_{2.5}, \mathrm{BC}$, and $\mathrm{OC}$ emissions. A root mean square error (RMSE) between the two inventories for $\mathrm{PM}_{2.5}, \mathrm{BC}$, and $\mathrm{OC}$ are calculated as $0.3,6.0$ and 3.5 tons grid ${ }^{-1} \mathrm{y}^{-1}$ and an index of agreement (Willmott, 1981; Jaiprakash et al., 2010) between the two inventories found as $1.0,0.99$ and 0.99 for $\mathrm{PM}_{2.5}$, $\mathrm{BC}$, and $\mathrm{OC}$ respectively, indicating a good agreement between present work and previous work by Sadavarte and Venkataraman (2014).

\section{Atmospheric BC Burden Due to Emissions from the Road Transport Sector}

The emission estimates of carbonaceous aerosols are then used in CAM5 global climate model to estimate the atmospheric burden and DRF due to BC emissions from on- road transport in India. As mentioned earlier the model simulations are performed from 1 December 2009 to 31 December 2015, with the first one month of model output excluded from our analyses to allow the model to spin up following the initial conditions. Fig. 5 shows the monthly mean climatology (2010-2015) of change in BC column burden (in $\mathrm{kg} \mathrm{m}^{-2}$ ) for all months from January to December over the South Asian region due to BC emissions from road transportation sector in India as estimated by the CAM5 model based on the difference of results from two simulations with and without $\mathrm{BC}$ emissions from road transportation sector in India. Interestingly, although there is no monthly variation in the emissions of aerosols from the road transport sector in our simulations, significant monthly variability is noted in the contribution of road transportation sector emissions from India towards the column burden of BC over South Asia. This monthly variability in the column burden of $\mathrm{BC}$ as noticeable in Fig. 5 despite using identical BC emissions for all months occurs primarily due to differences in the atmospheric transport pathways and the scavenging rate of aerosols from the atmosphere during different months. Fig. 6 shows the annual cycle of monthly mean climatology (2010-2015) of atmospheric BC burden (in $\mathrm{kg} \mathrm{m}^{-2}$ ) of India along with $\mathrm{BC}$ deposition rate (in $\mathrm{kg} \mathrm{m}^{-2} \mathrm{~s}^{-1}$ ), and precipitation rate (in $\mathrm{mm} \mathrm{day}^{-1}$ ) simulated by the CAM5 model with prescribed meteorology from MERRA-2. As light winds characterize the meteorological conditions over most parts of the Indian subcontinent during the months from December to March at the surface (Fig. 5) as well as at upper levels (not shown) and with insignificant precipitation (Fig. 6), it facilitates the stagnation of air and exacerbates BC and other pollutant levels in the atmosphere (Ganguly et al., 2006). During December-March period, light winds at the surface along with stable conditions in the atmospheric boundary layer and limited convection hinders dilution of BC levels in the atmosphere due to weaker horizontal and vertical transport of aerosols, while insignificant precipitation during the same period prevents washout of aerosols and light upper-level winds associated with slow-moving synoptic systems allow accumulation and buildup of $\mathrm{BC}$ burden during these months. In fact, as the prevailing surface-level wind flow during the months from December to March is predominantly from the Indian subcontinent toward the Indian Ocean (Fig. 5), large amount of $\mathrm{BC}$ emitted from road transport sector in India is transported over the Bay of Bengal and the Arabian Sea, resulting in significantly increased column burden of BC not only over the continental regions but also over these otherwise pristine oceanic regions.

On the contrary, the meteorological conditions over the Indian subcontinent during the period from June to September characterized by strong southwesterly winds near the surface bringing relatively pristine marine air over the polluted continental region (Fig. 5), convectively unstable atmosphere allowing faster horizontal and vertical transport of aerosols thereby diluting the $\mathrm{BC}$ concentrations within the atmospheric boundary layer and facilitating cloud processing of BC aerosols mixed with other water-soluble species (Hoose et al., 2006), and significant precipitation across the Indian region due to southwest monsoon resulting in efficient 

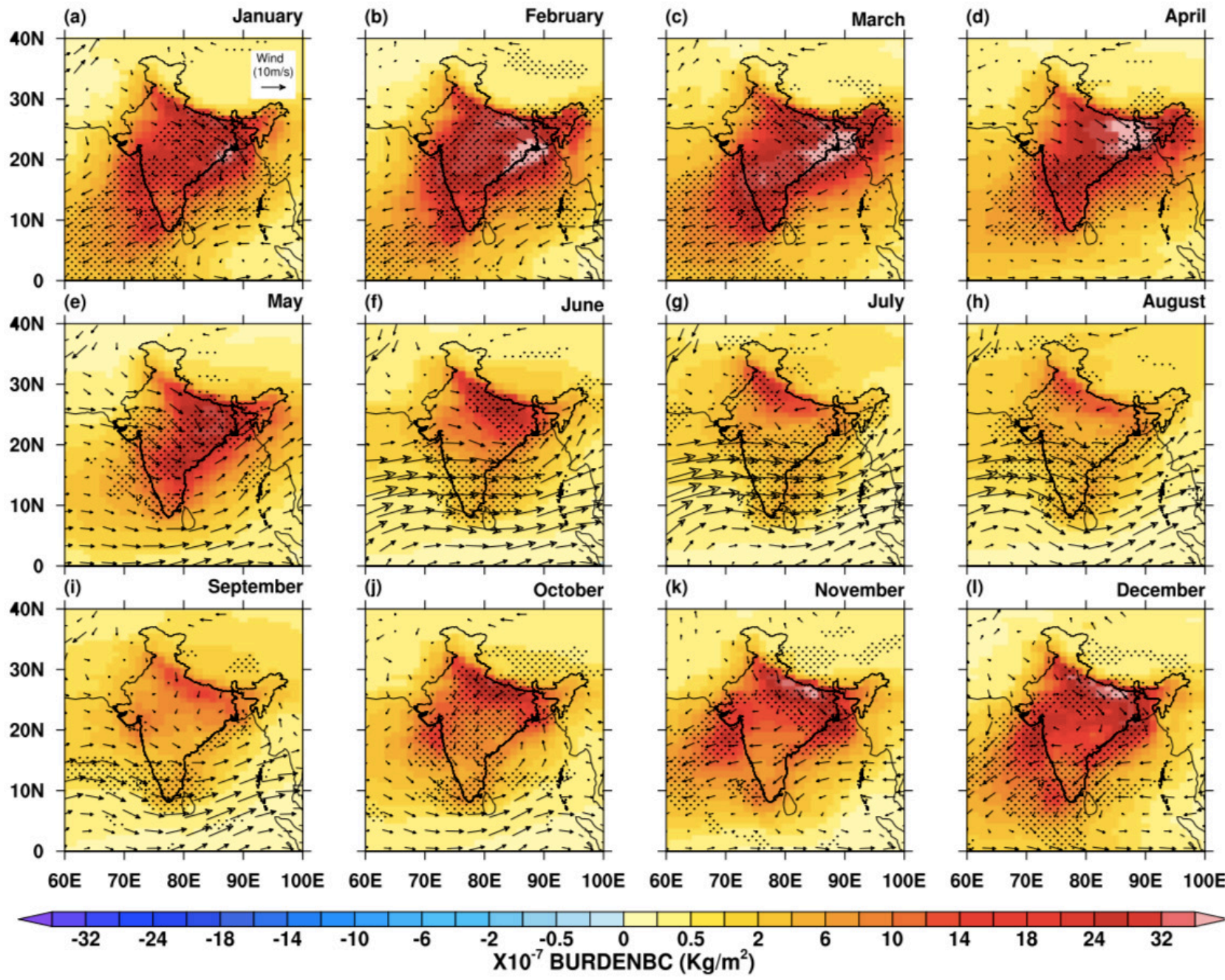

Fig. 5. Monthly mean climatology (2010-2015) of change in BC column burden $\left(\mathrm{kg} \mathrm{m}^{-2}\right)$ over the South Asian region due to $\mathrm{BC}$ emissions from road transportation sector in India as estimated by the CAM5 model and also shown are the wind vectors at $850 \mathrm{hPa}$ from MERRA-2. Stipples in this figure represent areas where the anomalies are at or exceed the $95 \%$ confidence level based on the Student's $t$-test.

wet scavenging (both in-cloud and below-cloud removal) of $\mathrm{BC}$ aerosols from the atmosphere (Fig. 6). As mentioned previously by Ganguly et al. (2012a) that since BC is largely co-emitted with other soluble species, it is rapidly converted to an internally mixed hydrophilic aerosol in the CAM5 model thereby facilitating the uptake of these $\mathrm{BC}$-containing internally mixed hydrophilic aerosols into cloud droplets which further undergoes rapid growth through collisioncoalescence process into larger hydrometeors and eventually gets rapidly scavenged from the atmosphere during the monsoon season. Thus we show using the scavenging rates of aerosols available from our simulations that it is mainly due to efficient scavenging of $\mathrm{BC}$ aerosols and stronger winds during the southwest monsoon season (June-September) that the contribution of emissions from the road transportation sector in India towards the $\mathrm{BC}$ burden in the atmosphere is found to be lowest, while the lower scavenging rates of aerosols and calm wind conditions result in higher $\mathrm{BC}$ burden during the March-April period, despite considering no change in emission rates of $\mathrm{BC}$ from the road transportation sector throughout the year in our simulations. In general, the column burden of $\mathrm{BC}$ is found to be higher over the Indo-Gangetic belt region compared to other parts of India due to higher emissions of $\mathrm{BC}$ from the road transportation sector from this major source region as shown in Fig. S4.

\section{Radiative Forcing Due to BC Emissions from the Road Transport Sector}

Fig. 7 shows the monthly mean climatology (2010-2015) of the spatial distributions of the shortwave direct radiative forcing at TOA for all months from January to December over the South Asian region due to $\mathrm{BC}$ emissions from the road transport sector in India. Since the magnitude of the shortwave DRF due to OC emissions from the road transportation sector is found to be more than an order of magnitude smaller than the DRF due to $\mathrm{BC}$ emissions from the same sector, we limit our discussions to the radiative effects of BC emissions alone in the present work. Spatial distributions of shortwave DRF at TOA for individual months from January to December over the South Asian 

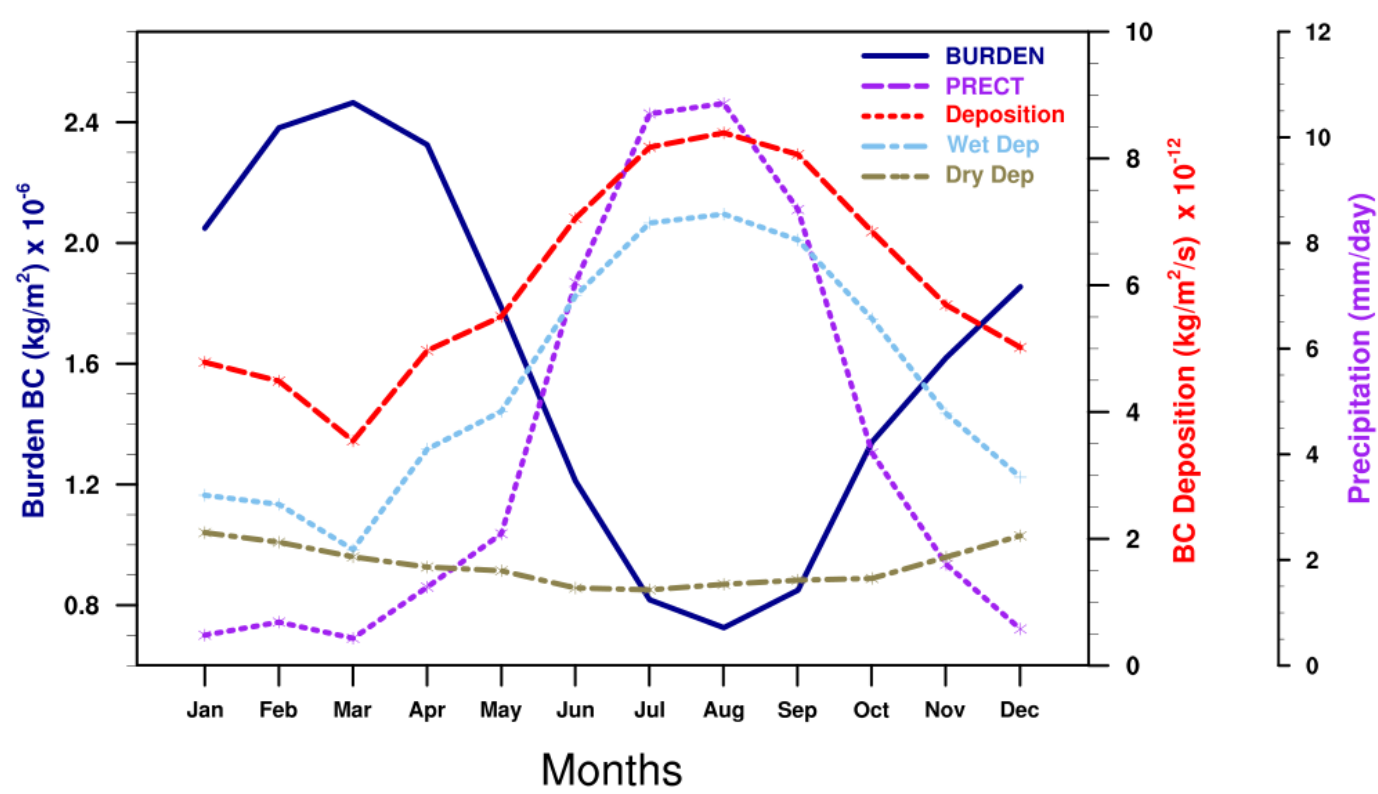

Fig. 6. Annual cycle of monthly mean climatology (2010-2015) of average atmospheric BC burden (kg $\left.\mathrm{m}^{-2}\right)$ in India, BC deposition rate $\left(\mathrm{kg} \mathrm{m}^{-2} \mathrm{~s}^{-1}\right)$, and precipitation rate (PRECT in $\mathrm{mm}$ day ${ }^{-1}$ ) simulated by the CAM5 model. Decomposition of total $\mathrm{BC}$ deposition rate to wet and dry deposition rates is also shown in the figure.

a) DRF at Surface $\left(\mathrm{W} / \mathrm{m}^{2}\right)$

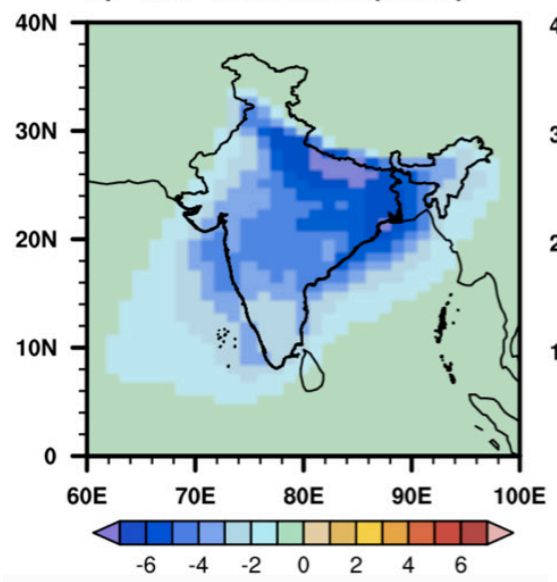

b) DRF at TOA $\left(\mathrm{W} / \mathrm{m}^{2}\right)$

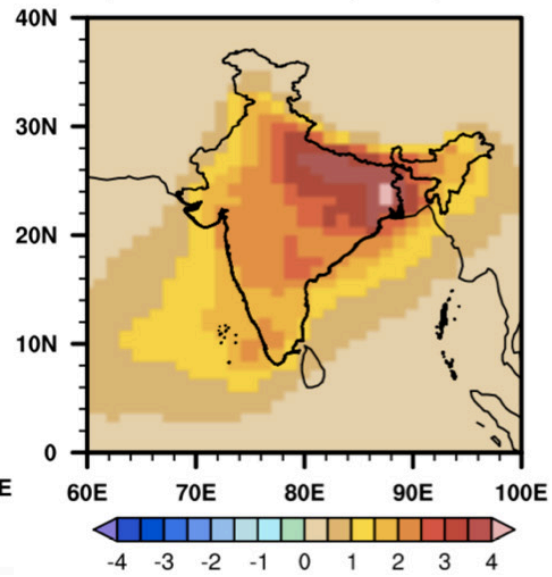

c) Atmospheric DRF $\left(\mathrm{W} / \mathrm{m}^{2}\right)$

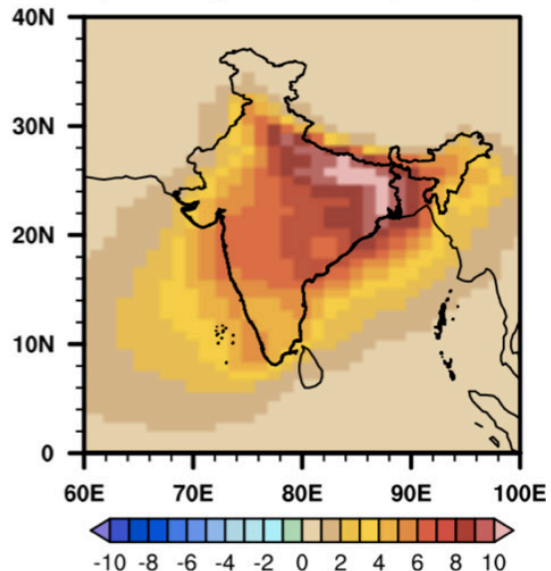

Fig. 7. Annual mean climatology (2010-2015) of direct radiative forcing ( $\mathrm{W} \mathrm{m}^{-2}$ ) (a) at surface, (b) at TOA, and (c) within the atmosphere over the South Asian region due to $\mathrm{BC}$ emissions from road transportation sector in India as estimated by the CAM5 model.

region due to $\mathrm{BC}$ emissions from the road transport sector in India is shown in Fig. S5. The positive DRF at TOA estimated during all months with values up to approximately $6 \mathrm{~W} \mathrm{~m}^{-2}$ indicates a warming effect over the South Asian region due to $\mathrm{BC}$ emissions from the road transportation sector in India. The spatial distributions of DRF at TOA (Fig. S5) for all months are similar but not identical to the pattern of change in BC column burden (Fig. 5), and these differences are likely due to the differences in clouds between the two simulations. It is worth emphasizing here that the radiative fluxes under both all-sky and clean-sky conditions are influenced somewhat differently not just due to differences in $\mathrm{BC}$ aerosols between the two simulations, but also due to differences in clouds, and the presence of $\mathrm{BC}$ aerosols relative to (above or below) those clouds under allsky conditions between the simulations (Ghan et al., 2012). This happens because as discussed earlier in Section 2.7 that the methodology adopted in this study for the calculation of aerosol radiative forcing ensures that while our estimates of DRF includes the radiative warming enhancement by BC aerosols present above clouds or other bright surfaces, it avoids exaggeration of radiative cooling by scattering aerosols above clouds. However, unlike the positive DRF at TOA, BC emissions from road transportation sector in India results in a predominantly negative DRF at the surface across the South Asian region and thereby leading to a net loss of shortwave radiation at the surface by up to around $10 \mathrm{~W} \mathrm{~m}^{-2}$ over certain areas especially in the eastern part of 
the Indo-Gangetic belt in some months (Figs. 7, S5, and S6). In fact, as noted earlier in the case of spatial distribution of atmospheric BC burden shown in Fig. 5, the extent of negative DRF at the surface extends well beyond the source regions of these aerosols over the Indian land mass to far-off areas over the Bay of Bengal and the Arabian Sea, particularly during the months from December to April when the prevailing low-level wind is predominantly from the Indian subcontinent toward the Indian Ocean and large amounts of BC emitted from the Indian land mass is transported over these oceanic regions (Fig. S6). Thus while a positive DRF at the TOA (Fig. 7) refers to a gain of additional energy for the earthatmosphere system by up to $6 \mathrm{~W} \mathrm{~m}^{-2}$, a negative DRF at the surface in spite of this gain of energy at the TOA means that there is a net loss of energy at the surface of the earth by up to $10 \mathrm{~W} \mathrm{~m}^{-2}$, thereby indicating a trapping of energy within the atmosphere by up to $16 \mathrm{~W} \mathrm{~m}^{-2}$ due to the direct radiative effects of $\mathrm{BC}$ emissions from the road transportation sector in India and as estimated by taking the difference of the DRF values at the TOA and surface (Figs. 7 and S7). Fig. 8 shows annual cycle of monthly mean climatology (2010-2015) of $\mathrm{BC}$ direct radiative forcing averaged over the Indian region at surface, TOA, and within the atmosphere as estimated by the CAM5 model. The annual cycles of $\mathrm{BC}$ direct radiative forcing (Fig. 8) follows the same pattern as the BC column burden shown earlier in Fig. 6. We find the DRF at surface to be maximum (in terms of magnitude) during March when the $\mathrm{BC}$ column burden is also highest due to a buildup of BC associated with weaker horizontal and vertical transport of aerosols and less scavenging of aerosols due to insignificant precipitation during this time of the year, while DRF at surface to be lower (in terms of magnitude) during monsoon season due to lesser BC column burden during this season. We also find that the annual cycle of atmospheric absorption due to BC (Fig. 8) as estimated by taking the difference between DRF at the TOA and DRF at surface, closely follows the annual cycle of $\mathrm{BC}$ column burden (Fig. 6) thereby showing that the atmospheric DRF due to $\mathrm{BC}$ is directly proportional to the $\mathrm{BC}$ column burden in the atmosphere.

As discussed earlier in Section 3.3 that the emission estimates of BC from the road transportation sector, as reported in this study are associated with an uncertainty of about $50 \%$. Hence, with an aim to understand the uncertainty in our estimates of DRF due to $\mathrm{BC}$ aerosols arising due to the uncertainty in emissions of $\mathrm{BC}$ from the transportation sector in India, we perform two additional model sensitivity experiments where in one case we increased the $\mathrm{BC}$ emissions from the road transportation sector in India by $50 \%$ and in the other case, we decreased the same emissions by $50 \%$ of the mean value used previously in our standard simulation (see Section 2.6 for the simulation setup of these sensitivity experiments). In addition to providing us an idea about the uncertainty associated with our estimates of DRF, another usefulness of the results of our sensitivity simulations is that it also helps us to answer policy-relevant question such as the change in $\mathrm{BC}$ forcing that we can expect to get from changes in emissions caused by either future emission increases or implementation of deliberate mitigation measures involving cutting down emissions of BC. Fig. 9 shows the scatter plot of monthly mean DRF at TOA, surface, and atmosphere with increase in column burden of $\mathrm{BC}$ for individual model grid points within India as well as averaged over all grid points across India from the three sensitivity experiments. Our estimates of DRF due to BC from these sensitivity experiments reveal that the DRF remains uncertain up to approximately $35 \%$ due to uncertainties in the emission estimates of $\mathrm{BC}$ from transportation sector in India. Interestingly our results suggest that the DRF at TOA, surface, and atmosphere due to $\mathrm{BC}$ aerosols exhibit an approximately linear relationship with column mass burden of $\mathrm{BC}$ across the Indian region and for the range of $\mathrm{BC}$ emissions considered in this study. Since the estimates of $\mathrm{BC}$ emissions and hence the column mass burden of $\mathrm{BC}$ over the Indian region continue to remain uncertain, this linear relationship between the column burden

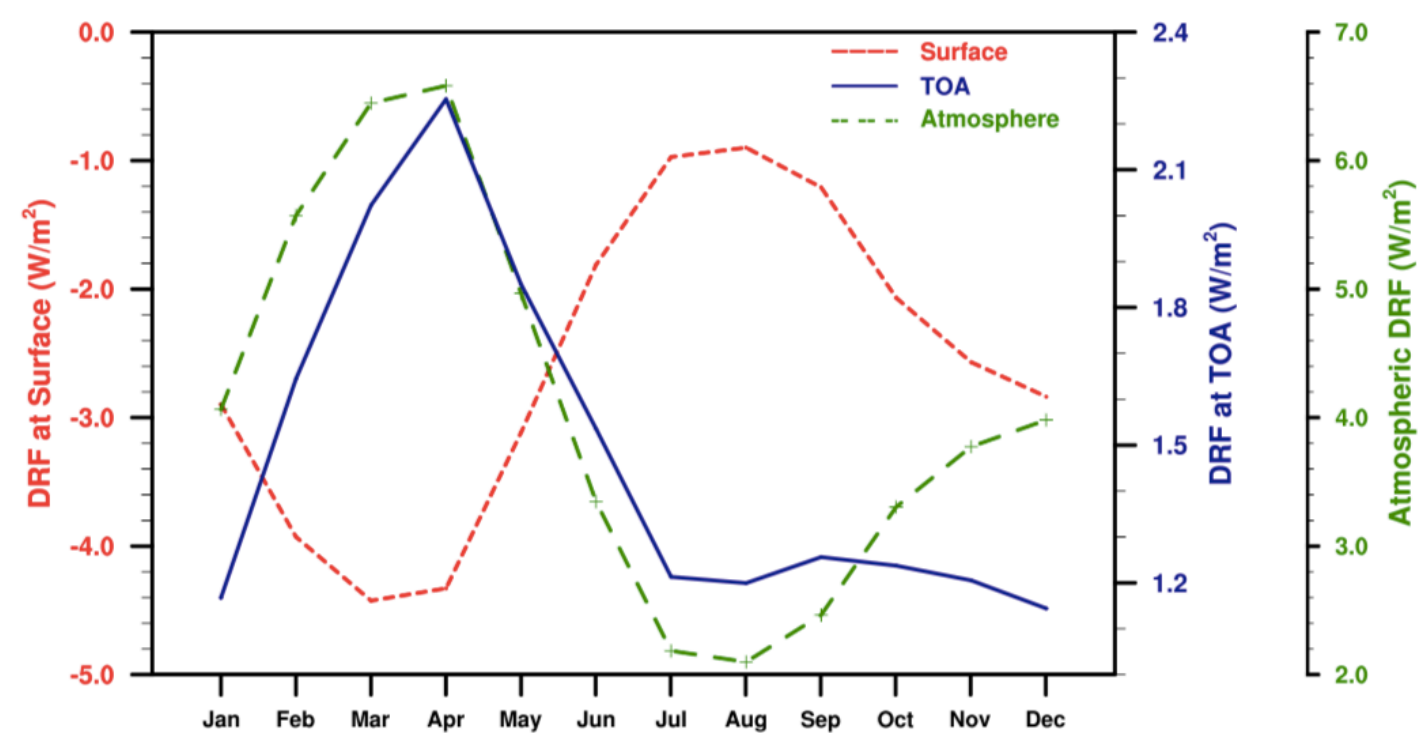

Fig. 8. Annual cycle of monthly mean climatology (2010-2015) of BC direct radiative forcing (W $\mathrm{m}^{-2}$ ) averaged over the Indian region at surface, TOA, and within the atmosphere as estimated by the CAM5 model. 

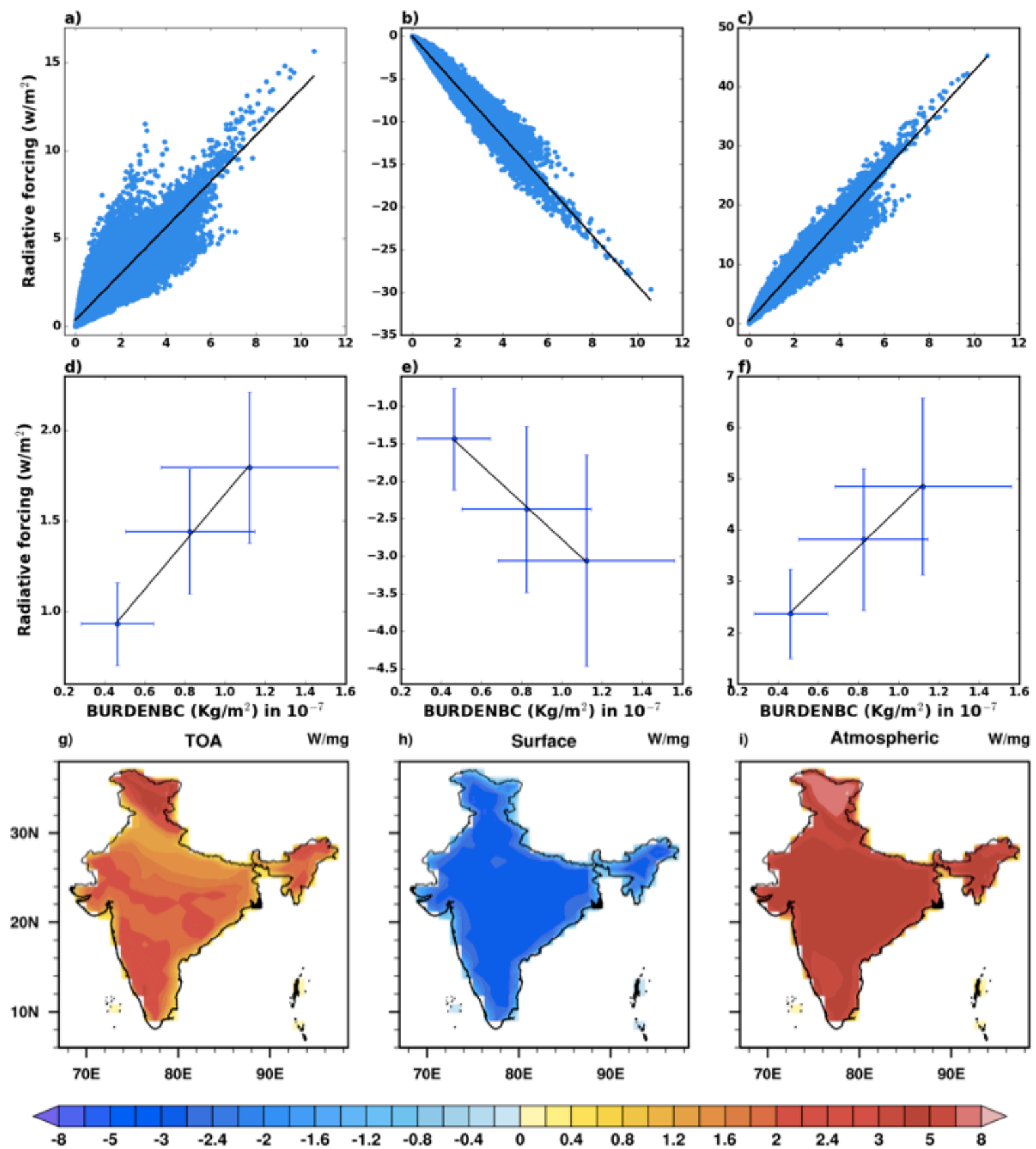

Fig. 9. Scatter plot of monthly mean direct radiative forcing $\left(\mathrm{W} \mathrm{m}^{-2}\right)$ at TOA, surface, and atmosphere with increase in column burden of $\mathrm{BC}\left(\mathrm{kg} \mathrm{m}^{-2}\right)$ for individual model grid points within India (panels (a), (b), and (c) respectively) and averaged over entire India (panels (d), (e), and (f) respectively) from the control experiment and two additional sensitivity experiments for the period 2010-2015. Horizontal and vertical bars in panels (d), (e), and (f) represent the standard deviation in $\mathrm{BC}$ burden and radiative forcing values across all grid points within India about their mean values in the respective experiments. Annual mean climatology (2010-2015) of normalized DRF (in units of $\mathrm{W} \mathrm{mg}{ }^{-1}$ ) at TOA, surface, and the atmosphere due to $\mathrm{BC}$ aerosols are shown in panels $(\mathrm{g}),(\mathrm{h})$, and (i) respectively.

of $\mathrm{BC}$ and the DRF due to $\mathrm{BC}$ aerosols allows us a more useful way of presenting the DRF due to $\mathrm{BC}$ as the normalized DRF or the DRF per unit column mass burden of BC in watts per milligram $\left(\mathrm{W} \mathrm{mg}^{-1}\right)$. Fig. 9 also shows the annual mean climatology (2010-2015) of normalized DRF at TOA, surface, and the atmosphere due to $\mathrm{BC}$ aerosols. We find the normalized DRF at TOA, surface, and atmosphere due to BC averaged over India to be around $+1.3,-2.5$, and $+3.8 \mathrm{~W} \mathrm{mg}^{-1}$ respectively with an uncertainty of about $61 \%$ due to uncertainties in the DRF and column mass burden of BC. It is worth noting from Fig. 9 that unlike the spatial distributions of DRF due to BC (Fig. 7), the spatial distributions of 
normalized DRF due to $\mathrm{BC}$ appears to be significantly different from the pattern of change in $\mathrm{BC}$ column burden (Fig. 5) and in fact the normalized DRF due to $\mathrm{BC}$ appears to be more spatially uniform in general and particularly for the normalized DRF values at the surface. The spatial homogeneity in normalized DRF due to $\mathrm{BC}$ at the surface (Fig. 9(h)) regardless of the actual column burden of BC exhibiting significant variability across the Indian region (Fig. S8) is also evident from the strong linear correlation between the increase in column burden of $\mathrm{BC}$ and the DRF due to $\mathrm{BC}$ at the surface (Fig. 9(b)). Thus, our estimates of normalized DRF due to $\mathrm{BC}$ is also useful for knowing the change in $\mathrm{BC}$ forcing that we can expect to achieve from either future emission increases or implementation of mitigation measures involving cutting down $\mathrm{BC}$ emissions from particular sectors. Interestingly, our results show that the spatial variability of the normalized DRF due to BC at TOA (Fig. 9(g)) is not only significantly different from the pattern of change in $\mathrm{BC}$ column burden, but also the normalized DRF due to BC at TOA gets amplified over areas characterized by the presence of these strongly absorbing $\mathrm{BC}$ aerosols above highly reflective surface including clouds (Figs. S9 and S10). For example, the normalized DRF at TOA and atmospheric absorption due to $\mathrm{BC}$ noted over Jammu and Kashmir in the north and western side of the peninsular India in the south (Figs. 9(g) and 9(i)) in spite of significantly lower column burden of $\mathrm{BC}$ existing over both these regions compared to highly polluted regions elsewhere such as the Indo-Gangetic belt (Figs. 5 and S8) are noted primarily due to higher surface albedo over Jammu and Kashmir in the north (Fig. S9) and persistent presence of highly reflecting low clouds over the western side of the peninsular India (Figs. S10 and S11) almost throughout the year resulting in an absorption amplification of shortwave radiation per unit column burden of $\mathrm{BC}$ over these regions. Consequences of such high values of normalized DRF at TOA and atmospheric warming due to $\mathrm{BC}$ over the Himalayan Karakoram region as well as over the peninsular India are not easy to speculate, but it is surely a subject of further investigation by the scientific community to understand the potential impact of such enhanced atmospheric warming on the melting of snow and glaciers over the Himalayan region as well as on the onset of the South Asian summer monsoon, regional climate and the hydrological cycle (Ramanathan et al., 2005; Lau et al., 2006; Meehl et al., 2008; Randles et al., 2008; Lau et al., 2010; Ganguly et al., 2012b; Yoon et al., 2016).

Previous studies have shown that while the aerosolinduced negative forcing at the surface resulting in a cooling of the surface including the sea surface temperatures over the northern Indian Ocean during the pre-monsoon season (March-May) could lead to a weakening of the South Asian summer monsoon system (Ramanathan et al., 2005; Chung et al., 2006; Ganguly et al., 2012a), the BC-induced trapping of energy within the atmosphere resulting in a warming up of the lower troposphere where the $\mathrm{BC}$ aerosols are mostly confined could also increase the near-surface atmospheric instability thereby intensifying the monsoon system (Lau et al., 2006; Meehl et al., 2008; Wang et al., 2009; Ganguly et al., 2012b). Hence, we wish to mention here that while the ultimate impact of carbonaceous aerosol emissions on the South Asian monsoon system and the regional climate continues to be an important research question, which demands further investigation involving improved regional emissions from all sectors, but it is beyond the scope of the present study, and therefore it will be taken up as a separate study in the future.

\section{SUMMARY AND CONCLUSIONS}

Using detailed EFs for on-road vehicles categorized by age to decrease the uncertainty associated with the emission estimates, new emission inventories for the $\mathrm{PM}_{2.5}, \mathrm{BC}$, and OC for the on-road transport sector in India during 2013 were developed. The total national consumption of fuel (diesel, gasoline, and $\mathrm{CNG}$ ) was estimated and then disaggregated at the state level. We discovered that the category of superemitter vehicles contributed nearly $53-68 \%$ of the total $\mathrm{PM}_{2.5}, \mathrm{BC}$, and $\mathrm{OC}$ emissions from the on-road transport sector, with emissions from a super-emitter vehicle being significantly higher than those from a non-super-emitter. The continued growth of the GDP and urban population will likely result in a steep rise in the number of on-road vehicles across India in the coming years; therefore, increased gaseous and particulate matter emissions are expected. In addition, the current trends of poor vehicle maintenance and the absence of after-treatment technologies will likely elevate emissions of climate-relevant pollutants, which may severely affect the climate and local air quality, causing various health problems.

We substituted IPCC AR5's default estimates of carbonaceous aerosol emissions from the road transport sector with figures from our newly developed local emission inventory for India and merged our data with the global emission inventory. Using the CAM5 global climate model, we then estimated the $\mathrm{BC}$ column burden in the atmosphere and the aerosol direct radiative forcing due to $\mathrm{BC}$ emissions from the road transport sector in India. Our model simulations indicate that although the column burden of BC is generally higher over the Indo-Gangetic belt than other parts of the subcontinent regardless of the month, large quantities of BC emitted from this sector are transported across the Bay of Bengal and the Arabian Sea, resulting in a significantly increased column burden of BC over these oceanic regions. The $\mathrm{BC}$ emissions associated with this sector result in a positive DRF, with values of up to $6 \mathrm{~W} \mathrm{~m}^{-2}$, at the TOA, suggesting that they cause a warming effect across the South Asian region. Despite the gain in energy at the TOA, a predominantly negative DRF, revealing a net energy loss of up to $10 \mathrm{~W} \mathrm{~m}^{-2}$, was observed at the surface. The total estimated DRF values $\left(16 \mathrm{~W} \mathrm{~m}^{-2}\right)$ indicate that energy remains trapped within the atmosphere above the Indian subcontinent solely because of the road transportation sector. Furthermore, the normalized DRF (the DRF per unit column mass burden of BC) attributable to the total $\mathrm{BC}$ averaged across India at the TOA, at the surface, and in the atmosphere was estimated to be approximately $+1.3,-2.5$, and $+3.8 \mathrm{~W} \mathrm{mg}^{-1}$, respectively, with an uncertainty of $\sim 61 \%$ due to uncertainties in the DRF and the column mass burden of BC. In spite of column burdens of $\mathrm{BC}$ that were significantly lower than elsewhere in India, 
such as the Indo-Gangetic belt, we found exceptionally high values for the normalized DRF at the TOA and for atmospheric absorption due to BC over the region of Jammu and Kashmir in the north as well as the western side of peninsular India due to higher surface albedo in the former and the persistent presence of highly reflective low clouds in the latter, which amplified the absorption of shortwave radiation per unit column burden of BC. Finally, although the overall effect of carbonaceous aerosol emissions on the South Asian monsoon system is undoubtedly a critical issue, which demands further investigation and a decrease in regional emissions from all sectors, it is beyond the scope of the present study.

\section{ACKNOWLEDGMENTS}

This work was supported by Department of Science and Technology, India, under fast-track scheme (SR/FTP/ES183/2010). We are grateful to Dr. Sarath Guttikunda, and Pankaj Sadavarte for helpful suggestions.

\section{SUPPLEMENTARY MATERIAL}

Supplementary data associated with this article can be found in the online version at http://www.aaqr.org.

\section{REFERENCES}

Alves, C.A., Lopes, D.J., Calvo, A.I., Evtyugina, M., Rocha, S. and Nunes, T. (2015). Emissions from light-duty diesel and gasoline in-use vehicles measured on chassis dynamometer test cycles. Aerosol Air Qual. Res. 15: 99116. doi: 10.4209/aaqr.2014.01.0006.

ARAI (2008). Emission factor development for Indian vehicles. In Air quality monitoring project - Indian clean air programme. The Automotive Research Association of India, Pune.

ARAI (2009). Source profiling for vehicular emissions. In Air quality monitoring project - Indian clean air programme. The Automotive Research Association of India, Pune. http://www.cpcb.nic.in/Source_Profile_Vehicles.pdf.

Baidya, S. and Borken-Kleefeld, J. (2009). Atmospheric emissions from road transportation in India. Energy Policy 37: 3812-3822. doi: 10.1016/j.enpol.2009.07.010.

Bond, T.C., Streets, D.G., Yarber, K.F., Nelson, S.M., Woo, J.H. and Klimont, Z. (2004). A technology-based global inventory of black and organic carbon emissions from combustion. J. Geophys. Res. 109: D14203. doi: 10.1029/ 2003JD003697.

Bond, T.C., Doherty, S.J., Fahey, D.W., Forster, P.M., Berntsen, T., Deangelo, B.J., Flanner, M.G., Ghan, S., Kärcher, B., Koch, D., Kinne, S., Kondo, Y., Quinn, P.K., Sarofim, M.C., Schultz, M.G., Schulz, M., Venkataraman, C., Zhang, H., Zhang, S., Bellouin, N., Guttikunda, S.K., Hopke, P.K., Jacobson, M.Z., Kaiser, J.W., Klimont, Z., Lohmann, U., Schwarz, J.P., Shindell, D., Storelvmo, T., Warren, S.G. and Zender, C.S. (2013). Bounding the role of black carbon in the climate system: A scientific assessment. J. Geophys. Res. 118: 5380-5552. doi: 10.1002/ jgrd.50171.

Borken, J., Steller, H., Merétei, T. and Vanhove, F. (2008). Global and country inventory of road passenger and freight transportation: Fuel consumption and emissions of air pollutants in year 2000. Transp. Res. Rec. 2011: 127136. doi: 10.3141/2011-14.

Choudhary, A. and Gokhale, S. (2016). Urban real-world driving traffic emissions during interruption and congestion. Transp. Res. Part D 43: 59-70. doi: 10.1016/j.trd.2015.12. 006.

Chung, C.E. and Ramanathan, V. (2006). Weakening of North Indian SST Gradients and the Monsoon Rainfall in India and the Sahel. J. Clim. 19: 2036-2045. doi: 10.1175/JCLI3820.1

Crippa, M., Guizzardi, D., Muntean, M., Schaaf, E., Dentener, F., van Aardenne, J.A., Monni, S., Doering, U., Olivier, J.G., Pagliari, V. and Janssens-Maenhout, G. (2018). Gridded emissions of air pollutants for the period 1970-2012 within EDGAR v4. 3.2. Earth System Science Data. 10: 1987-2013. doi: 10.5194/essd-10-1987-2018.

Fuglestvedt, J., Berntsen, T., Myhre, G., Rypdal, K. and Skeie, R.B. (2008). Climate forcing from the transport sectors. PNAS 105: 454-458. doi: 10.1073/pnas.0702958 104.

Ganguly, D., Jayaraman, A., Rajesh, T.A. and Gadhavi, H. (2006). Wintertime aerosol properties during foggy and nonfoggy days over urban center Delhi and their implications for shortwave radiative forcing. J. Geophys. Res. 111: D15217, doi: 10.1029/2005JD007029.

Ganguly, D., Rasch, P.J., Wang, H. and Yoon, J.H. (2012a). Climate response of the South Asian monsoon system to anthropogenic aerosols. J. Geophys. Res. 117: D13209. doi:10.1029/2012JD017508.

Ganguly, D., Rasch, P.J., Wang, H. and Yoon, J.H. (2012b). Fast and slow responses of the South Asian monsoon system to anthropogenic aerosols. Geophys. Res. Lett. 39: L18804. doi: 10.1029/2012GL053043.

Ghan, S.J. and Zaveri, R.A. (2007). Parameterization of optical properties for hydrated internally mixed aerosol. $J$. Geophys. Res. 112: D10201. doi: 10.1029/2006JD007927.

Ghan, S.J., Liu, X., Easter, R.C., Zaveri, R., Rasch, P.J., Yoon, J.H. and Eaton, B. (2012). Toward a minimal representation of aerosols in climate models: Comparative decomposition of aerosol direct, semidirect, and indirect radiative forcing. J. Clim. 25: 6461-6476. doi: 10.1175/J CLI-D-11-00650.1.

Ghan, S.J. (2013). Technical note: Estimating aerosol effects on cloud radiative forcing 9971-9974. Atmos. Chem. Phys. 13: 9971-9974. doi: 10.5194/acp-13-99712013.

Goel, R. and Guttikunda, S.K. (2015). Evolution of on-road vehicle exhaust emissions in Delhi. Atmos. Environ. 105: 78-90. doi: 10.1016/j.atmosenv.2015.01.045.

Grieshop, A.P., Boland, D., Reynolds, C.C.O., Gouge, B., Apte, J.S., Rogak, S.N. and Kandlikar, M. (2012). Modeling air pollutant emissions from Indian autorickshaws: Model development and implications for fleet emission rate estimates. Atmos. Environ. 50: 148-156. doi: 10.1016/j.atmosenv.2011.12.046. 
Guttikunda, S.K. and Mohan, D. (2014). Re-fueling road transport for better air quality in India. Energy Policy 68: 556-561. doi: 10.1016/j.enpol.2013.12.067.

Habib, G., Venkataraman, C., Shrivastava, M., Banerjee, R., Stehr, J.W. and Dickerson, R.R. (2004). New methodology for estimating biofuel consumption for cooking: Atmospheric emissions of black carbon and sulfur dioxide from India. Global Biogeochem. Cycles 18: GB3007. doi: 10.1029/2003GB002157.

Habib, G., Venkataraman, C., Bond, T.C. and Schauer, J.J. (2008). Chemical, microphysical and optical properties of primary particles from the combustion of biomass fuels. Environ. Sci. Technol. 42: 8829-8834. doi: 10.1021/es80 $0943 \mathrm{f}$

He, K., Huo, H., Zhang, Q., He, D., An, F., Wang, M. and Walsh, M.P. (2005). Oil consumption and $\mathrm{CO}_{2}$ emissions in China's road transport: Current status, future trends, and policy implications. Energy Policy 33: 1499-1507. doi: 10.1016/j.enpol.2004.01.007.

Hoose, C., Lohmann, U., Bennartz, R., Croft, B. and Lesins, G. (2008). Global simulations of aerosol processing in clouds. Atmos. Chem. Phys. 8: 6939-6963. doi: 10.5194/a cp-8-6939-2008.

Huo, H., Yao, Z., Zhang, Y., Shen, X., Zhang, Q. and He, K. (2012). On-board measurements of emissions from diesel trucks in five cities in China. Atmos. Environ. 54: 159 167. doi: 10.1016/j.atmosenv.2012.01.068.

Hurrell, J.W., Holland, M.M., Gent, P.R., Ghan, S., Kay, J.E., Kushner, P.J., Lamarque, J.-F., Large, W.G., Lawrence, D., Lindsay, K., Lipscomb, W.H., Long, M.C., Mahowald, N., Marsh, D.R., Neale, R.B., Rasch, P., Vavrus, S., Vertenstein, M., Bader, D., Collins, W.D., Hack, J.J., Kiehl, J. and Marshall, S. (2013). The Community Earth System Model: A Framework for Collaborative Research. Bull. Am. Meteorol. Soc. 94: 1339-1360. doi: 10.1175/BAMS-D-12-00121.1.

Iacono, M.J., Delamere, J.S., Mlawer, E.J., Shephard, M.W., Clough, S.A. and Collins, W.D. (2008). Radiative forcing by long-lived greenhouse gases: Calculations with the AER radiative transfer models. J. Geophys. Res. 113: D13103. doi: 10.1029/2008JD009944.

Institute for Health Metrics and Evaluation (IHME) (2013). GBD Profile: India. Institute for Health Metrics and Evaluation, Seattle, USA

IPCC (2013.) IPCC fifth assessment report: Climate change 2013. Intergovernmental Panel on Climate Change. doi: 10.1017/ CBO9781107415324.005.

Jaiprakash, P., Singh, G. and Pal, A. (2010). Air pollution dispersion modeling performace for mining complex. Int. J. Environ. Sci. Technol. 5: 205-22.

Jaiprakash, Habib, G. and Kumar, S. (2016). Evaluation of portable dilution system for aerosol measurement from stationary and mobile combustion sources. Aerosol Sci. Technol. 50: 717-731. doi: 10.1080/02786826.2016.117 8502.

Jaiprakash and Habib, G. (2017). Chemical and optical properties of $\mathrm{PM}_{2.5}$ from on-road operation of light duty vehicles in Delhi city. Sci. Total Environ. 586: 900-916. doi: 10.1016/j.scitotenv.2017.02.070.
Jaiprakash and Habib, G. (2018). A technology-based mass emission factors of gases and aerosol precursor and spatial distribution of emissions from on-road transport sector in India. Atmos. Environ. 180: 192-205. doi: 10.1016/j.atmosenv.2018.02.053.

Kim Oanh, N.T., Thiansathit, W., Bond, T.C., Subramanian, R., Winijkul, E. and Paw-armart, I. (2009). Compositional characterization of $\mathrm{PM}_{2.5}$ emitted from in-use diesel vehicles. Atmos. Environ. 44: 15-22. doi: 10.1016/j.atmo senv.2009.10.005.

Klimont, Z., Cofala, J., Xing, J., Wei, W., Zhang, C., Wang, S., Kejun, J., Bhandari, P., Mathur, R., Purohit, P., Rafaj, P., Amann, M., Chambers, A. and Hao, J. (2009). Projections of $\mathrm{SO}_{2}, \mathrm{NO}_{\mathrm{x}}$ and carbonaceous aerosols emissions in Asia. Tellus Ser. B 61: 602-617. doi: 10.1111/j.16000889.2009.00428.x.

Lacey, F. and Henze, D. (2015). Global climate impacts of countrylevel primary carbonaceous aerosol from solidfuel cookstove emissions. Environ. Res. Lett. 10: 114003. doi: 10.1088/1748-9326/10/11/114003.

Lamarque, J.F., Kyle, G.P., Meinshausen, M., Riahi, K., Smith, S.J., van Vuuren, D.P., Conley, A.J. and Vitt, F. (2011). Global and regional evolution of short-lived radiatively-active gases and aerosols in the Representative Concentration Pathways. Clim. Change 109: 191-212. doi: 10.1007/s10584-011-0155-0.

Lau, K.M., Kim, M.K. and Kim, K.M. (2006). Asian summer monsoon anomalies induced by aerosol direct forcing: The role of the Tibetan Plateau. Clim. Dyn. 26: 855-864. doi: 10.1007/s00382-006-0114-z.

Lau, W.K.M., Kim, M.K., Kim, K.M. and Lee, W.S. (2010). Enhanced surface warming and accelerated snowmelt in the Himalayas and Tibetan Plateau induced by absorbing aerosols. Environ. Res. Lett. 5: 025204, doi: 10.1088/17489326/5/2/025204.

Lin, S.J. (2004). A "vertically Lagrangian" finite-volume dynamical core for global models. Mon. Weather Rev. 132: 2293-2307. doi: 10.1175/1520-0493(2004)132<229 3:AVLFDC>2.0.CO;2.

Liu, X., Easter, R.C., Ghan, S.J., Zaveri, R., Rasch, P., Shi, X., Lamarque, J.F., Gettelman, A., Morrison, H., Vitt, F., Conley, A., Park, S., Neale, R., Hannay, C., Ekman, A.M.L., Hess, P., Mahowald, N., Collins, W., Iacono, M.J., Bretherton, C.S., Flanner, M.G. and Mitchell, D. (2012). Toward a minimal representation of aerosols in climate models: Description and evaluation in the Community Atmosphere Model CAM5. Geosci. Model Dev. 5: 709-739. doi: 10.5194/gmd-5-709-2012.

Lu, Z., Zhang, Q. and Streets, D.G. (2011). Sulfur dioxide and primary carbonaceous aerosol emissions in China and India, 1996-2010. Atmos. Chem. Phys. 11: 9839-9864. doi: 10.5194/acp-11-9839-2011.

Ma, P.L., Rasch, P.J., Wang, M., Wang, H., Ghan, S.J., Easter, R.C., Gustafson, W.I., Liu, X., Zhang, Y. and Ma, H.Y. (2015). How does increasing horizontal resolution in a global climate model improve the simulation of aerosol-cloud interactions? Geophys. Res. Lett. 42: 50585065. doi: 10.1002/2015GL064183.

Meehl, G.A., Arblaster, J.M. and Collins, W.D. (2008). 
Effects of black carbon aerosols on the Indian monsoon. J. Clim. 21: 2869-2882. doi: 10.1175/2007JCLI1777.1.

Ministry of Road Transport and Highways (MORTH) (2013). Road transport year book 2012-13. Ministry of Road Transport and Highways, Government of India, New Delhi, India.

Neale, R.B., Chen, C.C., Lauritzen, P.H., Williamson, D.L., Conley, A.J., Smith, A.K., Mills, M. and Morrison, H. (2004). Description of the NCAR Community Atmosphere Model (CAM 5.0). NCAR Tech. Note NCAR/TN4861STR, National Center for Atmospheric Research (NCAR).

Ohara, T., Akimoto, H., Kurokawa, J., Horii, N., Yamaji, K., Yan, X. and Hayasaka, T. (2007). An Asian emission inventory of anthropogenic emission sources for the period 1980-2020. Atmos. Chem. Phys. 7: 4419-4444. doi: 10.5194/acp-7-4419-2007.

Paliwal, U., Sharma, M. and Burkhart, J.F. (2016). Monthly and spatially resolved black carbon emission inventory of India: Uncertainty analysis. Atmos. Chem. Phys. 16: 12457-12476. doi: 10.5194/acp-16-12457-2016.

Pandey, A. and Venkataraman, C. (2014). Estimating emissions from the Indian transport sector with on-road fleet composition and traffic volume. Atmos. Environ. 98: 123-133. doi: 10.1016/j.atmosenv.2014.08.039.

Pandey, A., Sadavarte, P., Rao, A.V. and Venkataraman, C. (2014). A technology-linked multi-pollutant inventory of Indian energy-use emissions: II. Residential, agricultural and informal industry sectors. Atmos. Environ. 99: 341352. doi: 10.1016/j.atmosenv.2014.09.080.

Ramachandra, T.V. and Shwetmala (2009). Emissions from India's transport sector: State-by-state synthesis. Atmos. Environ. 43: 5510-5517. doi: 10.1016/j.atmosenv.2009.07. 015.

Ramachandra, T.V., Aithal, B.H. and Sreejith, K. (2015). GHG footprint of major cities in India. Renewable Sustainable Energy Rev. 44: 473-495. doi: 10.1016/j.rser. 2014.12.036.

Ramanathan, V., Chung, C., Kim, D., Bettge, T., Buja, L., Kiehl, J.T., Washington, W.M., Fu, Q., Sikka, D.R. and Wild, M. (2005). Atmospheric brown clouds: Impacts on South Asian climate and hydrological cycle. PNAS 102: 5326-5333. doi: 10.1073/pnas.0500656102.

Randles, C.A. and Ramaswamy, V. (2008). Absorbing aerosols over Asia: A Geophysical Fluid Dynamics Laboratory general circulation model sensitivity study of model response to aerosol optical depth and aerosol absorption, J. Geophys. Res. 113: D21203. doi: 10.1029/ 2008JD010140.

Reddy, M.S. and Venkataraman, C. (2002). Inventory of aerosol and sulphur dioxide emissions from India: IFossil fuel combustion. Atmos. Environ. 36: 677-697. doi: 10.1016/S1352-2310(01)00463-0.

Reynolds, C.C.O., Grieshop, A.P. and Kandlikar, M. (2011). Climate and health relevant emissions from in-use indian three-wheelers fueled by natural gas and gasoline. Environ. Sci. Technol. 45: 2406-2412. doi: 10.1021/es102430p.

Sadavarte, P. and Venkataraman, C. (2014). Trends in multipollutant emissions from a technology-linked inventory for India: I. Industry and transport sectors. Atmos. Environ. 99: 353-364. doi: 10.1016/j.atmosenv.2014.09.081.

Sahu, S.K., Beig, G. and Sharma, C. (2008). Decadal growth of black carbon emissions in India. Geophys. Res. Lett. 35: L02807. doi: 10.1029/2007GL032333.

Sharma, M. and Dikshit, O. (2016). Comprehensive Study on Air Pollution and Green House Gases (GHGs) in Delhi. Indian Institute of Technology Kanpur, India.

SIAM (2010). The Indian Automobile Industry: Statistical Profile 2009-2010 (New Delhi, India).

Singh, C., Ganguly, D. and Dash, S.K. (2018). On the dust load and rainfall relationship in South Asia: An analysis from CMIP5. Clim. Dyn. 50: 403-422. doi: 10.1007/s003 82-017-3617-x.

Streets, D.G., Bond, T.C., Carmichael, G.R., Fernandes, S.D., Fu, Q., He, D., Klimont, Z., Nelson, S.M., Tsai, N.Y., Wang, M.Q., Woo, J.H. and Yarber, K.F. (2003). An inventory of gaseous and primary aerosol emissions in Asia in the year 2000. J. Geophys. Res. 108: 8809. doi: 10.1029/2002JD003093.

Subramanian, R., Winijkul, E., Bond, T.C., Thiansathit, W., Oanh, N.T., Paw-armart, I. and Duleep, K.G. (2009). Climate-relevant properties of diesel particulate emissions: Results from a piggyback study in Bangkok, Thailand. Environ. Sci. Technol. 43: 4213-4218. doi: 10.1021/es80 32296.

Tilmes, S., Lamarque, J.F., Emmons, L.K., Kinnison, D.E., Ma, P.L., Liu, X., Ghan, S., Bardeen, C., Arnold, S., Deeter, M., Vitt, F., Ryerson, T., Elkins, J.W., Moore, F., Spackman, J.R. and Val Martin, M. (2015). Description and evaluation of tropospheric chemistry and aerosols in the Community Earth System Model (CESM1.2). Geosci. Model Dev. 8: 1395-1426. doi: 10.5194/gmd-8-13952015.

U.S. EIA (2013). International energy outlook 2013. U.S. Energy Information Administration, Washington, USA, DOE/EIA-0484(2013). www.eia.gov/forecasts/ieo/pdf/0 484(2013).pdf.

U.S. EPA (2011). AP-42: Compilation of air pollutant emission factors. Appendix H: Highway mobile source emission factors tables. United States Environmental Protection Agency, USA.

van Vuuren, D.P., Edmonds, J., Kainuma, M., Riahi, K., Thomson, A., Hibbard, K., Hurtt, G.C., Kram, T., Krey, V., Lamarque, J.F., Masui, T., Meinshausen, M., Nakicenovic, N., Smith, S.J. and Rose, S.K. (2011). The representative concentration pathways: An overview. Clim. Change 109: 5-31. doi: 10.1007/s10584-011-0148-z.

Venkataraman, C., Habib, G., Eiguren-Fernandez, A., Miguel, A.H. and Friedlander, S.K. (2005). Residential biofuels in South Asia: Carbonaceous aerosol emissions and climate Impacts. Science 307: 1454-1456. doi: 10.1126/science.1104359.

Wang, C., Kim, D., Ekman, A.M.L., Barth, M.C. and Rasch, P.J. (2009). Impact of anthropogenic aerosols on Indian summer monsoon. Geophys. Res. Lett. 36: L21704. doi: 10.1029/2009GL040114.

Wang, C. (2013). Impact of anthropogenic absorbing aerosols on clouds and precipitation: A review of recent progresses. 
Atmos. Res. 122: 237-249. doi: 10.1016/j.atmosres.2012. 11.005 .

Weyant, C., Athalye, V., Ragavan, S., Rajarathnam, U., Lalchandani, D., Maithel, S., Baum, E. and Bond, T.C. (2014). Emissions from South Asian brick production. Environ. Sci. Technol. 48: 6477-6483. doi: 10.1021/es50 0186g.

Willmott, C.J. (1981). On the validation of models. Phys. Geogr. 2: 184-194.

Yanowitz, J., Mccormick, R.L. and Graboski, M.S. (2000). In-use emissions from heavy-duty diesel vehicles. Environ. Sci. Technol. 34: 729-740. doi: 10.1021/es990903w.

Yoon, J.H., Rasch, P.J., Wang, H., Vinoj, V. and Ganguly, D. (2016). The role of carbonaceous aerosols on short-term variations of precipitation over North Africa. Atmos. Sci. Lett. 17: 407-414. doi: 10.1002/asl.672.
Zhang, Q., Streets, D.G., Carmichael, G.R., He, K.B., Huo, H., Kannari, A., Klimont, Z., Park, I.S., Reddy, S., Fu, J.S., Chen, D., Duan, L., Lei, Y., Wang, L.T. and Yao, Z.L. (2009). Asian emissions in 2006 for the NASA INTEX-B mission. Atmos. Chem. Phys. 9: 5131-5153. doi: 10.5194/acp-9-5131-2009.

Zielinska, B., Sagebiel, J., McDonald, J.D., Whitney, K. and Lawson, D.R. (2004). Emission rates and comparative chemical composition from selected in-use diesel and gasoline-fueled vehicles. J. Air Waste Manage. Assoc. 54: 1138-1150. doi: 10.1080/10473289.2004.10470973.

Received for review, August 16, 2019 Revised, November 24, 2019 Accepted, January 4, 2020 